ARTICLE

\title{
Th1 responses in vivo require cell-specific provision of OX4OL dictated by environmental cues
}

Dominika W. Gajdasik¹, Fabrina Gaspal ${ }^{1}$, Emily E. Halford (10 ${ }^{1}$, Remi Fiancette ${ }^{1}$, Emma E. Dutton ${ }^{1}$, Claire Willis ${ }^{1}$, Timo Rückert (10) ${ }^{2}$, Chiara Romagnani (10) 2, Audrey Gerard (10 ${ }^{3}$, Sarah L. Bevington ${ }^{4}$, Andrew S. MacDonald (1) ${ }^{5}$, Marina Botto (i) ${ }^{6}$, Timothy Vyse (i] ${ }^{7} \&$ David R. Withers (10) ${ }^{1 凶}$

The OX40-OX40L pathway provides crucial co-stimulatory signals for CD4 T cell responses, however the precise cellular interactions critical for OX4OL provision in vivo and when these occur, remains unclear. Here, we demonstrate that provision of OX4OL by dendritic cells (DCs), but not T cells, B cells nor group 3 innate lymphoid cells (ILC3s), is critical specifically for the effector Th1 response to an acute systemic infection with Listeria monocytogenes (Lm). OX4OL expression by DCs is regulated by cross-talk with NK cells, with IFN $\gamma$ signalling to the DC to enhance $\mathrm{OX} 40 \mathrm{~L}$ in a mechanism conserved in both mouse and human DCs. Strikingly, DC expression of OX4OL is redundant in a chronic intestinal Th1 response and expression by ILC3s is necessary. Collectively these data reveal tissue specific compartmentalisation of the cellular provision of $\mathrm{OX} 4 \mathrm{OL}$ and define a mechanism controlling DC expression of $\mathrm{OX} 40 \mathrm{~L}$ in vivo.

\footnotetext{
${ }^{1}$ Institute of Immunology and Immunotherapy, College of Medical and Dental Sciences, University of Birmingham, Birmingham, UK. ${ }^{2}$ Med. Klinik m.S. Gastroenterologie, Infektiologie und Rheumatologie and Deutsches Rheuma-Forschungszentrum, Charité - Universitätsmedizin Berlin, Berlin, Germany. ${ }^{3}$ The Kennedy Institute of Rheumatology, The University of Oxford, Oxford, UK. ${ }^{4}$ Institute of Cancer and Genomic Sciences, College of Medical and Dental Sciences, University of Birmingham, Birmingham, UK. ${ }^{5}$ Manchester Collaborative Centre for Inflammation Research, Faculty of Biology, Medicine and Health, University of Manchester, Manchester, UK. ${ }^{6}$ Department of Medicine, Centre for Inflammatory Disease, Imperial College London, London, UK. ${ }^{7}$ Division of Medical and Molecular Genetics and Immunology, Infection and Inflammatory Disease, King's College London, London, UK. ${ }^{\mathrm{e} e m a i l}$ : d.withers@bham.ac.uk
} 
P roductive $\mathrm{T}$ cell responses require interactions between costimulatory molecules in addition to signals conveyed through T cell receptor (TCR) engagement of peptide:major histocompatibility complex (MHC) complexes. Members of the tumour necrosis factor (TNF) receptor super family (TNFRSF) play critical roles in shaping $\mathrm{T}$ cell responses through sustaining proliferation, enhancing survival and directing cellular differentiation $^{1-5}$. CD4 $\mathrm{T}$ cell responses are particularly reliant on OX406, with $\mathrm{OX} 40^{-1-}$ and $\mathrm{OX} 40 \mathrm{~L}^{-1-}$ mice, alongside $\mathrm{OX} 40^{-1-}$ TCR transgenic T cells, all implicating OX40 signals in effector memory responses ${ }^{7-9}$. Furthermore, a human patient lacking functional OX40 expression was unable to make rapid effector cytokines upon challenge ${ }^{10}$, entirely consistent with the CD4 T cell defects observed in OX40-I- mice. Thus OX40 signals are thought to be critical in both generating effector CD4 $\mathrm{T}$ cell responses and the subsequent establishment of CD4 $\mathrm{T}$ cell memory. Since OX40 shares signalling pathways with its fellow TNFRSF member CD30, which is also induced upon $\mathrm{T}$ cell activation, there is also potential redundancy in the roles of these two molecules $2,11-13$.

Despite some understanding of the importance of OX40: OX40L at the molecular level, the cellular interactions underpinning provision of this costimulatory signal remain unclear. $\mathrm{T}$ helper type 1 (Th1) and Th2 responses are both thought to be OX40 dependent ${ }^{14-18}$, while the generation of Th17 cells may be inhibited by OX40 signals ${ }^{19}$. Expression of OX40L has been described on different professional antigen (Ag)-presenting cells $^{20,21}$ alongside $\mathrm{T}$ cells ${ }^{22}$, innate lymphoid cells ${ }^{23}$ and also non-haematopoietic populations ${ }^{24,25}$; thus many different cellular interactions may underpin the phenotypes observed in OX40and OX40L-deficient mice.

The activation of naive $\mathrm{T}$ cells within secondary lymphoid tissue is initiated through $\mathrm{T}$ cell interactions with Ag-bearing dendritic cells (DC) within the $\mathrm{T}$ zone $\mathrm{z}^{26-28}$. Thus DCs are obvious potential providers of costimulatory signals to activated $\mathrm{T}$ cells. However, after initial interactions with DCs, activated CD4 T cells migrate to the border between $\mathrm{B}$ and $\mathrm{T}$ zones and the interfollicular spaces, suggesting that some costimulatory ligands maybe provided by further cellular interactions that occur in distinct tissue microenvironments ${ }^{29}$. Cells isolated from secondary lymphoid tissue with the highest expression of OX40L were found to be lymphoid tissue-inducer cells (now considered a type of group 3 innate lymphoid cell (ILC3) $)^{23}$ and were located specifically within the interfollicular spaces of lymph nodes (LNs) and the functionally analogous bridging channels of the spleen $^{30,31}$. Given that these ILC3s were also found to express high levels of $\mathrm{CD} 30 \mathrm{~L}^{23,32}$, they might be key providers of costimulatory signals to activated $\mathrm{T}$ cells moving through the interfollicular spaces. Such interactions would be consistent with evidence that ILC3s support splenic CD4 T cell responses ${ }^{33}$. Alternatively or in addition, activated $\mathrm{T}$ cells may encounter OX40L expression by B cells ${ }^{14}$ or other $\mathrm{T}$ cells ${ }^{22}$. The question of whether specific cellular interactions are required after initial priming by DC remains an important mechanistic detail and answering this would facilitate efforts to manipulate CD4 T cell responses in vivo.

Here we use the reporting of effector cytokines by endogenous Ag-specific CD4 $\mathrm{T}$ cells to carefully dissect the provision of OX40L in vivo. Our data reveal that OX40:OX40L interactions are critical for the generation of functional Th1 effector cells in the response to acute systemic Listeria monocytogenes $(\mathrm{Lm})$ infection, and using conditional OX40L knockout mice, we show that the expression of OX40L by DCs but not by T cells, B cells or ILC3s was required. Expression of OX40L by DCs is dependent upon crosstalk with natural killer (NK) cells that results in early interferon- $\gamma(\mathrm{IFN} \gamma)$ production directly signalling to the DCs to upregulate OX40L expression. In contrast, within a chronic intestinal Th1 response, DC OX40L expression is redundant and ILC3 expression of OX40L is required. Together, these studies define distinct cellular providers of OX40L in vivo, revealing that compartmentalisation of these signals, dependent on the nature of the response and the microenvironments, occurs to elicit optimal CD4 effector T cell responses.

\section{Results}

IFN $\gamma$-producing Th1 effector $T$ cells are OX40 dependent. Studies in humans ${ }^{10}$ and mice $8,34,35$ indicate that effector CD4 T cell responses are highly OX40 dependent. To better understand the costimulatory requirements for $\mathrm{CD} 4$ effector cell function in vivo, mice deficient in both $\mathrm{CD} 30$ and OX40 $\left(\mathrm{CD} 30^{-1-} \times\right.$ OX $40^{-l-}$ ) were crossed with Great $\times$ Smart17A dual IFN $\gamma$ and interleukin (IL)-17A reporter (GS) mice ${ }^{36}$. This approach enables reporting of cytokine expression without ex vivo manipulation. Furthermore, when combined with assessment of endogenous CD4 $\mathrm{T}$ cell responses using MHCII tetramers allows for the careful analysis of CD4 T cell function versus impacts on Agspecific CD4 $\mathrm{T}$ cell numbers. Infection with an attenuated $\mathrm{Lm}$ expressing the $2 \mathrm{~W} 1 \mathrm{~S}$ peptide ( $L m-2 \mathrm{~W} 1 \mathrm{~S})$ strain was used to model an acute intracellular bacterial infection that could be tracked with 2W1S-specific MHCII tetramers ${ }^{37,38}$. This wellcharacterised model provides a robust means to carefully dissect a robust Th1 response in vivo. To assess the impact of CD30 and OX40 deficiency on the effector CD4 T cell response, GS and GS $\mathrm{CD} 30^{-1-} \times \mathrm{OX} 40^{-1-}$ mice were assessed at 7 days post infection (dpi) with $L m-2 \mathrm{~W} 1 \mathrm{~S}$, revealing a substantial CD44hi $2 \mathrm{~W} 1 \mathrm{~S}$ specifc CD4 $\mathrm{T}$ cell population in both mouse strains, with the absence of CD30 and OX40 resulting in an approximate 2-fold reduction in total Ag-specific CD4 T cells (Fig. 1a, b). Expression of IFN $\gamma$, revealed by enhanced yellow fluorescent protein (eYFP) expression, was restricted to CXCR5 ${ }^{-} 2 \mathrm{~W} 1 \mathrm{~S}$-specific $\mathrm{T}$ cells ${ }^{38}$, and notably, eYFP expression was almost completely absent in $\mathrm{CXCR}^{-}$2W1S-specific T cells isolated from GS CD $30^{-1-} \times$ OX $40^{-1-}$ mice (Fig. 1c, d). In contrast, the number of CXCR5 ${ }^{+}$ follicular 2W1S-specific cells was not significantly changed (Fig. 1e) consistent with previous data that the follicular $\mathrm{T}$ cell response to this attenuated $L m$ strain was not OX40 dependent ${ }^{34}$. Expression of the Th1 associated transcription factor T-bet was used to identify effector cells that might be unable to produce effector cytokines (Fig. 1f). Numbers of T-bet ${ }^{+}$CXCR5 $^{-}$2W1Sspecific $\mathrm{T}$ cells were reduced approximately 2-3-fold in the absence of CD30 and OX40 (Fig. 1g, h). This is compared to the tenfold loss in $\mathrm{eYFP}^{+} \mathrm{CXCR}^{-}{ }^{-}$W1S-specific $\mathrm{T}$ cells indicating that the most substantial defect in the response is the ability of the cells to make effector cytokines. To determine whether the lack of IFN $\gamma$-producing Th1 cells at $7 \mathrm{dpi}$ (the peak of the response) reflected an inability of these cells to survive after initial priming, the response was assessed at $4 \mathrm{dpi}$. Again, eYFP $+2 \mathrm{~W} 1 \mathrm{~S}$-specific CD4 T cells, but not CXCR5 ${ }^{+} 2 \mathrm{~W} 1 \mathrm{~S}-$-specific T cells, were heavily reduced in the absence of CD30 and OX40 (Fig. 1i-1) as observed at the peak of the response, suggesting that the effector Th1 cells were not being generated. Combined, these data reveal that, in the primary CD4 T cell response to $L m-2 \mathrm{~W} 1 \mathrm{~S}$ infection, the number of Th1 effector CD4 T cells was reduced in the absence of CD30 and OX40, reflecting the early loss of cytokine-producing Th1 effector cells.

To determine the individual contributions of CD30 and OX40 to the effector $\mathrm{T}$ cell response, the $2 \mathrm{~W} 1 \mathrm{~S}$ response at $7 \mathrm{dpi}$ in $\mathrm{OX} 40^{-1-}$ and $\mathrm{CD} 30^{-1-} \times \mathrm{OX} 40^{-/-}$mice was compared (Fig. 2a). Enumeration of total 2W1S-specific CD4 T cells (Fig. 2b), 2W1Sspecific Th1 effectors (Fig. 2c, d) and 2W1S-specific CXCR5 ${ }^{+}$ follicular cells (Fig. 2e) revealed that loss of OX40 signals 
a

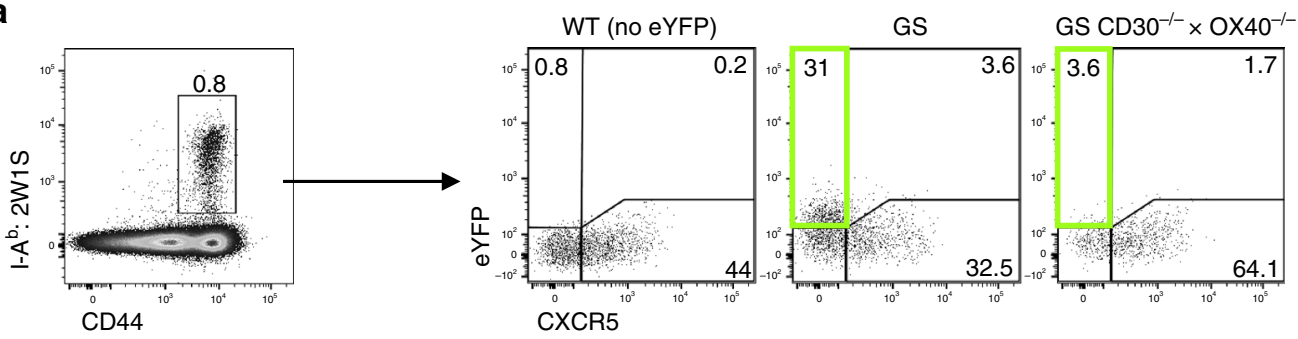

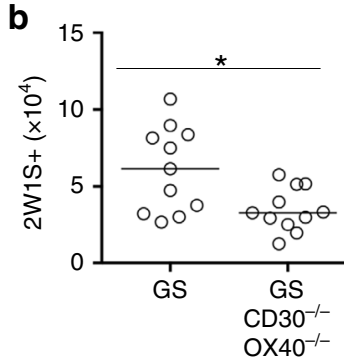

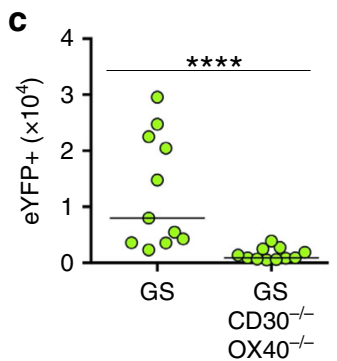

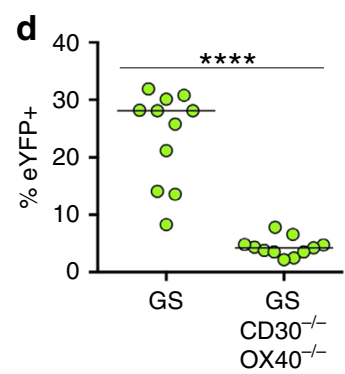

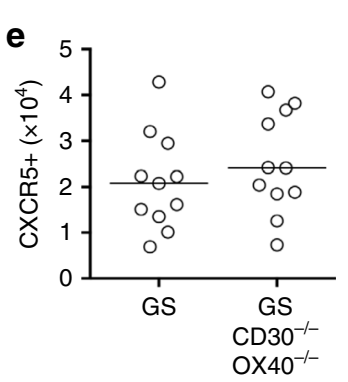

f

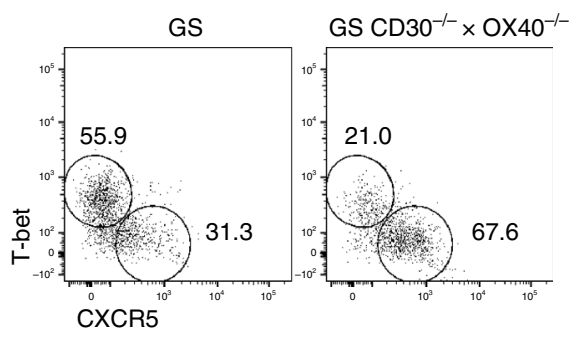

g
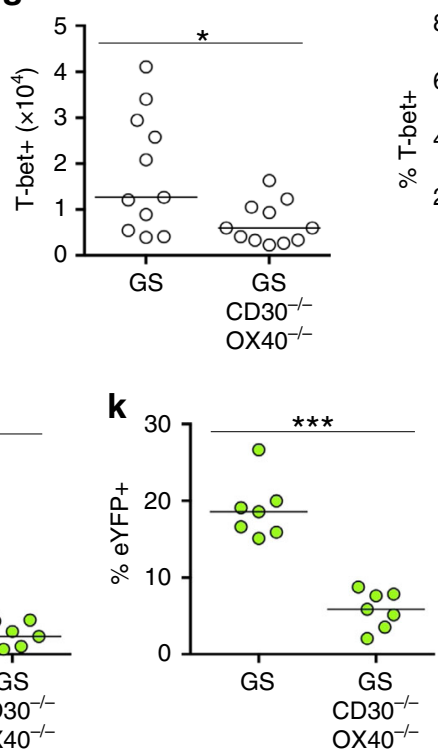

h

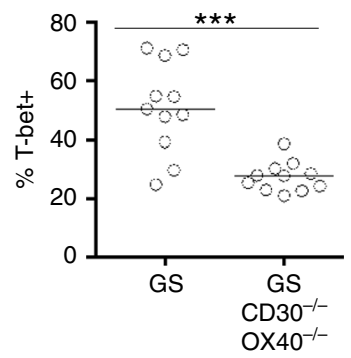

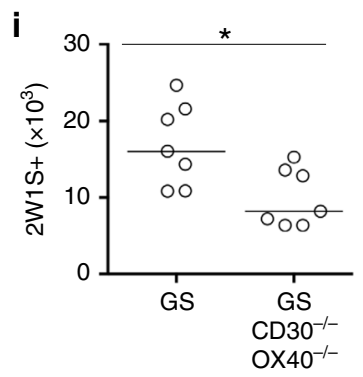
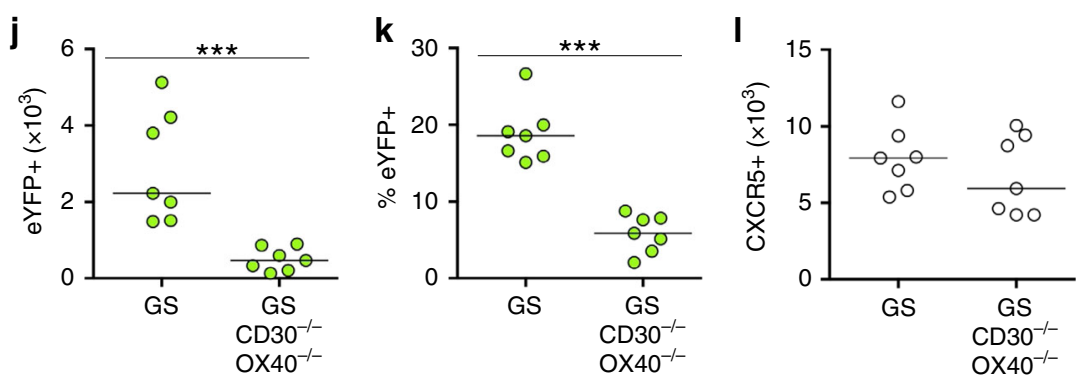

Fig. 1 Mice deficient in CD30 and OX40 show a dramatic decrease in reporting of IFN $\gamma$ production. To determine the requirement for CD30 and OX40 on CD4 T cell effector function without ex vivo manipulation, dual IFN $\gamma$ (eYFP) and IL-17A reporter mice (Great $\times$ Smart17A, GS) sufficient or deficient in

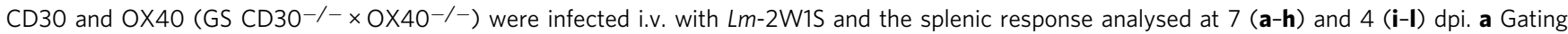

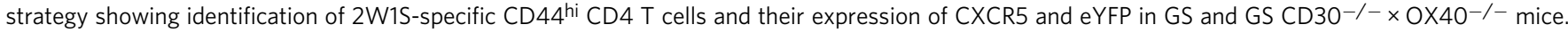
Gated on $\mathrm{CD}^{+}{ }^{+} \mathrm{CD} 4^{+}{ }^{+} 220^{-}{ }^{-}$CD11b-CD11 ${ }^{-}$cells; WT cells (lacking any eYFP) used to establish eYFP gating. Data are representative of 11 mice.

b Enumeration of 2W1S-specific CD4 T cells. c Enumeration of eYFP+ 2W1S-specific CD4 T cells. d Percentage of 2W1S-specific CD4 T cells expressing eYFP. e Enumeration of CXCR5 ${ }^{+}$2W1S-specific CD4 T cells. $\mathbf{f}$ Expression of T-bet versus CXCR5 by 2W1S-specific CD4 T cells. $\mathbf{g}$ Enumeration of T-bet ${ }^{+}$ 2W1S-specific CD4 T cells. h Percentage of 2W1S-specific CD4 T cells expressing T-bet. Data were pooled from 3 independent experiments $(n=11$ mice per group). i Enumeration of 2W1S-specific CD4 T cells. $\mathbf{j}$ Enumeration of eYFP+ 2W1S-specific CD4 T cells. $\mathbf{k}$ Percentage of 2W1S-specific CD4 T cells expressing eYFP. I Enumeration of CXCR5 ${ }^{+} 2 \mathrm{~W} 1 \mathrm{~S}$-specific CD4 T cells. Data were pooled from 2 independent experiments ( $n=7$ mice per group). Values on flow cytometric plots represent percentages; bars on scatter plots represents the median. Statistical significance was tested by using an unpaired, nonparametric, Mann-Whitney two-tailed $T$ test: ${ }^{\star} p \leq 0.05,{ }^{\star \star \star} p \leq 0.001,{ }^{\star \star \star \star} p \leq 0.0001$.

accounted for the defects observed in $\mathrm{CD} 30^{-1-} \times \mathrm{OX} 40^{-/-}$mice. Thus, for numbers of Ag-specific $\mathrm{T}$ cells at the peak of the response, OX40 expression was key. To determine whether CD30 played a role in the functional capacity of the Th1 effector population, GS mice with only single copies of either CD30 or OX40 (GS OX40 $0^{-/-} \mathrm{CD} 30^{-1+}$ and GS OX40 $0^{-/+} \mathrm{CD} 30^{-/-}$) were also generated. A single copy of OX40 in the absence of CD30 was sufficient for normal IFN $\gamma$ (eYFP) production (Fig. 2f, g) and formation of a T-bet ${ }^{+}$effector CD4 T cell population (Fig. 2h, i), indicating that these aspects of the response were not $\mathrm{CD} 30$ dependent. Combined, these experiments demonstrate that signals through $\mathrm{OX} 40$, rather than through $\mathrm{CD} 30$, were critical for the primary Th1 response induced by $L m-2 \mathrm{~W} 1 \mathrm{~S}$ infection. While OX40L is the only reported ligand for OX40, we confirmed that observations made in $\mathrm{OX} 40^{-1-}$ mice were consistent with mice lacking OX40L by crossing OX40 $\mathrm{L}^{\mathrm{f} / \mathrm{f}}$ mice $^{39}$ with $\mathrm{PGK}^{\text {cre }}$ mice (which express cre recombinase ubiquitously) to generate a total OX40L-deficient mouse model. As anticipated, 
a

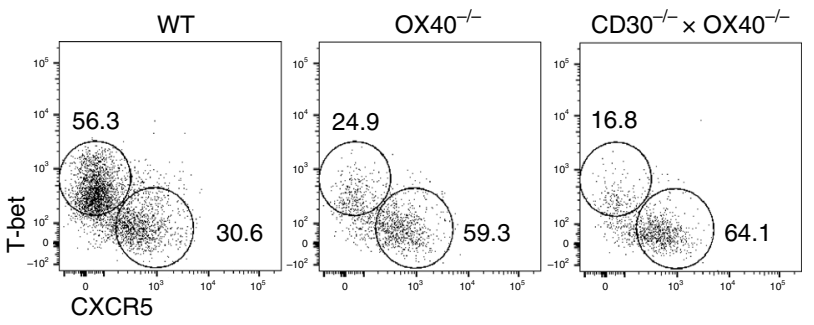

C
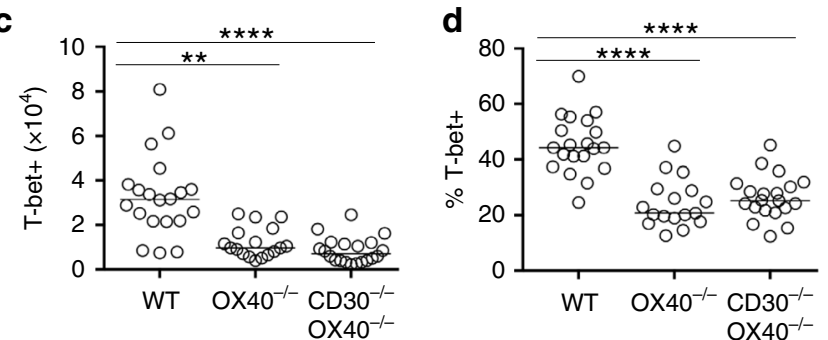

b

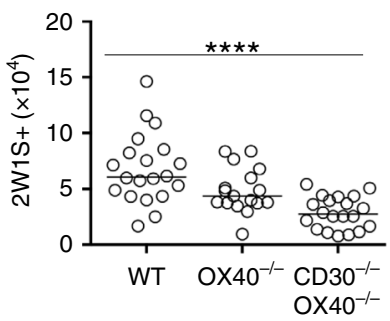

e

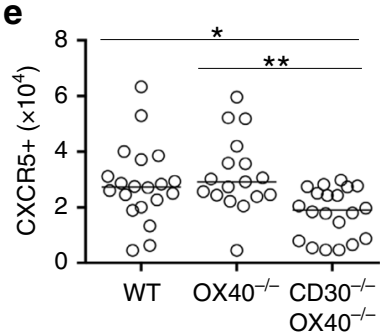

f

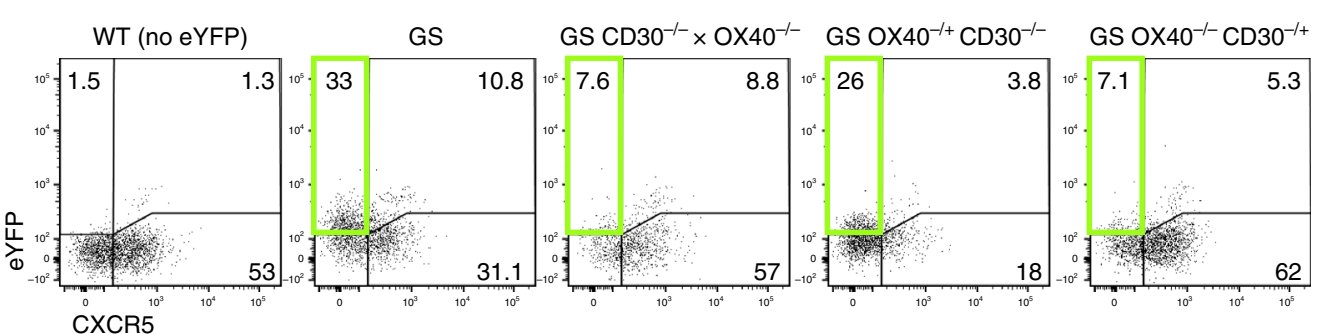

g

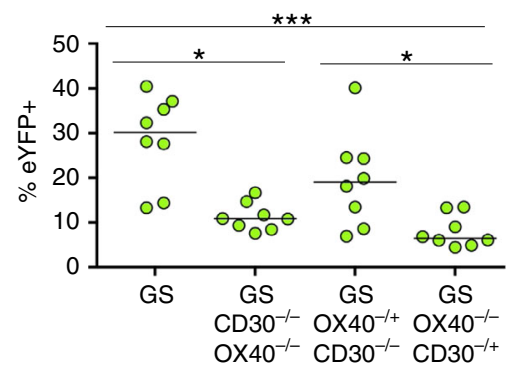

h

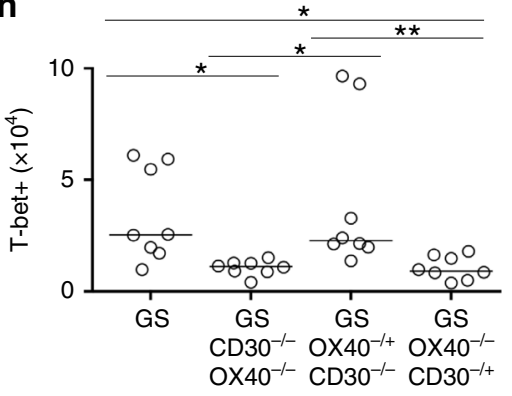

i

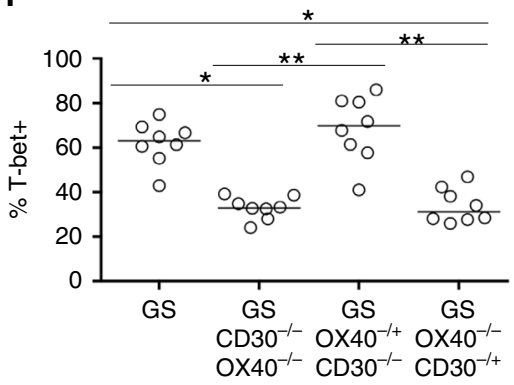

j

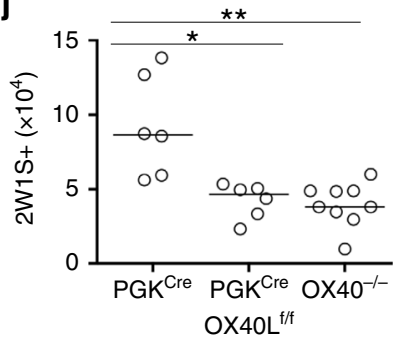

k

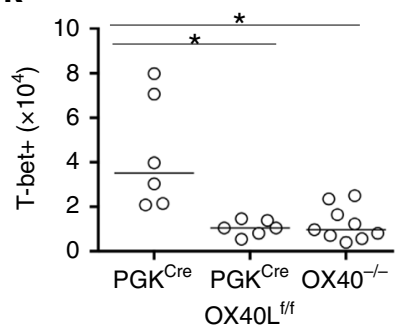

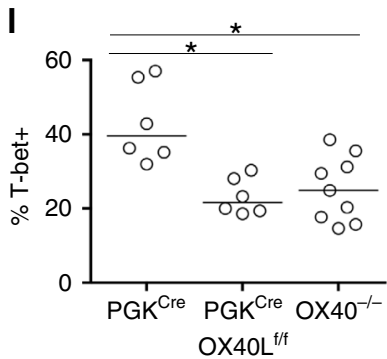

total $\mathrm{OX} 40^{-1-}$ or $\mathrm{PGK}^{\mathrm{cre}} \times \mathrm{OX} 40 \mathrm{~L}^{\mathrm{f} / \mathrm{f}}$ mice showed a comparable disruption of the effector Th1 response (Fig. $2 \mathrm{j}-\mathrm{l}$ ).

DC expression of OX40L is required in systemic Th1 response. The specific cellular providers of OX40L signals within secondary lymphoid tissue remain to be elucidated, with professional Agpresenting cells, T cells and ILC populations all possible sources in vivo. We hypothesised that in the response to $L m-2 \mathrm{~W} 1 \mathrm{~S}$ there was a critical cellular provider of OX40L signals that underpinned the CD4 effector $\mathrm{T}$ cell response. To test this, OX40L $\mathrm{L}^{\mathrm{f} / \mathrm{f}}$ mice were crossed with multiple cell-specific cre strains to target DCs, ILC3s, T cells and B cells, since all of these have been reported to express OX40L ${ }^{5}$. Specific deletion of OX40L expression on the appropriate populations was confirmed through analysis of splenocytes ex vivo alongside fate-mapping of cre expression (Supplementary Fig. 1). Given their expression of OX40L ${ }^{23,32}$, positioning in lymphoid tissue ${ }^{31}$ and support for splenic CD4 T cell responses ${ }^{33}$, we first hypothesised that ILC3 expression of OX40L was required for functional Th1 responses. To test this, Rorc $^{\text {cre }}$ versus Rorc ${ }^{\text {cre }} \times \mathrm{OX} 40 \mathrm{~L}^{\mathrm{f} / \mathrm{f}}$ mice were infected with $\mathrm{Lm}$ 2W1S and assessed at $7 \mathrm{dpi}$, alongside OX40-1- controls. Strikingly, no defect was observed in the $2 \mathrm{~W} 1 \mathrm{~S}$-specific response when ILC3 lacked OX40L (Fig. 3a-c), indicating that ILC3 provision of OX40L was not required for the generation of effector Th1 
Fig. 2 Th1 effector T cells but not CXCR5 ${ }^{+}$populations require OX40:0X40L interactions. The specific contribution of OX40:OX4OL interactions in the generation of Th1 effector CD4 T cells was determined in the response at 7 days post infection with $L m$-2W1S. The $2 \mathrm{~W} 1 \mathrm{~S}$ effector $\mathrm{T}$ cell response was assessed in OX40-/- versus CD30-/- $\times \mathrm{OX}^{-1} 0^{-/-}$mice. a Expression of T-bet versus CXCR5 by 2W1S-specific CD44hi CD4 T cells in WT, OX40-/and $\mathrm{CD}_{3} \mathrm{O}^{-/-} \times \mathrm{OX} 40^{-/-}$mice. b Enumeration of 2W1S-specific CD4 T cells. c Enumeration of T-bet +2 W1S-specific CD4 T cells. d Percentage of 2W1Sspecific CD4 T cells expressing T-bet. e Enumeration of CXCR5 +2 W1S-specific CD4 T cells. To dissect the individual requirement for CD30 versus OX40 in the production of IFN $\gamma$ by effector CD4 T cells, Great $\times$ Smart17A $\times$ CD30-/- $\times$ OX40-/- (GS CD30-/- $\left.\times \mathrm{OX}^{-1} 0^{-/-}\right)$mice were crossed with $\mathrm{CD} 30^{-/-}$or $\mathrm{OX} 40^{-/-}$mice to generate Great $\times$Smart17A mice with only a single functional copy of OX40 (GS CD30-/- $\times \mathrm{OX}^{-1} 0^{+/-}$) or $\mathrm{CD} 30(\mathrm{GS}$ $\left.\mathrm{CD} 30^{+/-} \times \mathrm{O}_{4} 40^{-/-}\right)$. The $2 \mathrm{~W} 1 \mathrm{~S}$-specific CD4 T cell response at 7 days post infection of these mice alongside controls was then assessed. $\mathbf{f}$ Gating strategy showing identification of 2W1S-specific CD44hi CD4 T cells and their expression of CXCR5 and eYFP; WT (lacking any eYFP) used to establish eYFP gating. $\mathbf{g}$ Percentage of 2W1S-specific CD4 T cells expressing eYFP. $\mathbf{h}$ Enumeration of T-bet ${ }^{+}$2W1S-specific CD4 T cells. i Percentage of 2W1Sspecific CD4 T cells expressing T-bet. Data were pooled from 3 independent experiments ( $n=8$ mice per group). To confirm that mice deficient in OX40L

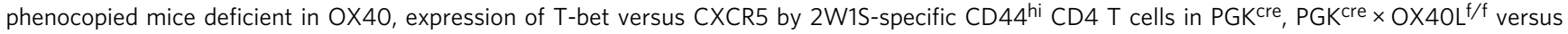
OX40-/- mice was assessed. j Enumeration of 2W1S-specific CD4 T cells. $\mathbf{k}$ Enumeration of T-bet ${ }^{+}$2W1S-specific CD4 T cells. I Percentage of 2W1Sspecific CD4 T cells expressing T-bet. Data were pooled from 2 independent experiments $\left(n=6 \mathrm{PGKCre}\right.$ mice, $n=6 \mathrm{PGKCre} \times \mathrm{OX}^{\mathrm{C}} \mathrm{OL} \mathrm{L}^{\mathrm{f} / \mathrm{f}}$ mice, $n=9$ OX40-/- mice). Values on flow cytometric plots represent percentages; bars on scatter plots represents the median. Statistical significance was tested by using an unpaired, non-parametric, Kruskal-Wallis one-way ANOVA with post hoc Dunn's test: ${ }^{\star} p \leq 0.05,{ }^{\star \star} p \leq 0.01,{ }^{\star \star \star} p \leq 0.001,{ }^{\star \star \star \star} p \leq 0.0001$.

responses in the spleen. Given that the defect in the Th1 effector response was established by $4 \mathrm{dpi}$, we hypothesised that DCs were the critical source of OX40L signal in vivo. To first confirm that the 2W1S-specific response to $L m-2 \mathrm{~W} 1 \mathrm{~S}$ was dependent upon interactions with DCs, MHCII expression by DCs was deleted using $\mathrm{CD} 11 \mathrm{c}^{\mathrm{cre}} \times \mathrm{H} 2 \mathrm{Ab}-1^{\mathrm{f} / \mathrm{f}}$ mice. As expected, in the absence of MHCII expression on CD11c ${ }^{+}$cells, the $2 \mathrm{~W} 1 \mathrm{~S}$-specific response was completely abrogated (Fig. $3 \mathrm{~d}$, e). To then test whether DC provision of OX40L was necessary for normal Th1 effector T cell responses, $\mathrm{CD} 11 \mathrm{c}^{\mathrm{cre}} \times \mathrm{OX} 40 \mathrm{~L}^{\mathrm{f} / \mathrm{f}}$ mice were infected with $\mathrm{Lm}$ 2W1S, alongside $\mathrm{CD} 11 \mathrm{c}^{\mathrm{cre}}$ and $\mathrm{CD} 30^{-1-} \times \mathrm{OX} 40^{-1-}$ controls. Compared with $\mathrm{CD} 11 c^{\text {cre }}$ controls, CD $11 c^{\text {cre }} \times \mathrm{OX} 40 \mathrm{~L}^{\mathrm{f} / \mathrm{f}}$ mice had significantly reduced numbers of $2 \mathrm{~W} 1 \mathrm{~S}$-specific CD4 T cells at 7 dpi (Fig. 3f, g) due to substantial loss of the T-bet ${ }^{+}$CXCR5 $^{-}$ subset (Fig. $3 \mathrm{~h}-\mathrm{j}$ ). Strikingly, the defects in $\mathrm{CD} 11 \mathrm{c}^{\mathrm{cre}} \times \mathrm{OX} 40 \mathrm{~L}^{\mathrm{f} / \mathrm{f}}$ mice were comparable to those observed in $\mathrm{CD} 30^{-1-} \times \mathrm{OX} 40^{-1-}$ controls, demonstrating that the expression of OX40L by DCs was absolutely required for the Th1 effector response and could account for the impaired Th1 effector response observed in the total absence of CD30 and OX40 signals. While these data clearly establish the importance of OX40L expression by DCs, we sought to further confirm that there was no absolute requirement for provision of OX40L by lymphocytes during the primary response, perhaps acting subsequent to interactions with DCs. Therefore, B cell-specific ( $\mathrm{Mb}^{\mathrm{cre}}$ ) and $\mathrm{T}$ cell-specific (CD4 $\left.{ }^{\text {cre }}\right)$ conditional OX40L-deficient mice were infected with $L m-2 \mathrm{~W} 1 \mathrm{~S}$ and the 2W1S-specific CD4 T cell response was analysed. No significant differences were observed versus cre-only controls in either strain confirming that there was no requirement for $\mathrm{B}$ nor $\mathrm{T}$ cell provision of OX40L in vivo for the normal response to $\mathrm{Lm}-2 \mathrm{~W} 1 \mathrm{~S}$ (Supplementary Fig. 2). Together, these data reveal that, in the primary response to $L m-2 \mathrm{~W} 1 \mathrm{~S}$, provision of OX40L by a single cellular source, the CD11c ${ }^{+}$DCs, is required for the Th1 effector $\mathrm{T}$ cell response.

Early IFN $\gamma$ regulates OX40L expression by DCs. Defining the cellular interaction required for provision of OX40L enabled the investigation into how expression of this key costimulatory pathway was regulated in vivo. The kinetics of DC expression of OX40L was assessed by infecting mice with $L m-2 \mathrm{~W} 1 \mathrm{~S}$ and then analysing splenic DC expression of OX40L at different time points post infection. Although a basal level of OX40L expression by the splenic DCs was evident, $L m-2 \mathrm{~W} 1 \mathrm{~S}$ infection resulted in the rapid upregulation of OX40L expression by $24 \mathrm{~h}$, which then declined to basal levels once more by $72 \mathrm{~h}$ post infection (Fig. 4a, b). The dynamics of OX40 expression relative to OX40L expression in the same spleen tissue was then assessed to better understand the relationship between maximal DC expression of the ligand and Ag-specific $\mathrm{T}$ cell expression of the receptor (Supplementary Fig. 3). OX40 expression was evident on 2W1S-specific CD4 T cells at $48 \mathrm{~h}$, where approximately $50 \%$ of the cells expressed OX40 and many also co-expressed CD25, described to be expressed by early Th1 effector $\mathrm{T}$ cells ${ }^{38}$. The proportion of OX40-expressing 2W1S-specific CD4 T cells peaked at 2 dpi and then rapidly decline such that by 4 dpi the vast majority of the responding $\mathrm{CD} 4 \mathrm{~T}$ cells lacked any detectable expression of OX40 and DC expression of OX40L had returned to baseline. Thus the expression of both OX40 and OX40L expression was focused very early in the response and OX40 expression was limited to only a proportion of the responding $2 \mathrm{~W} 1 \mathrm{~S}$-specific CD4 $\mathrm{T}$ cells with a phenotype consistent with Th1 effector cells.

While OX40L expression can be upregulated in vitro by stimulation through $\mathrm{CD} 40^{21}$, the rapid upregulation of OX40L expression observed after $L m-2 \mathrm{~W} 1 \mathrm{~S}$ infection suggested that early signals from innate immune cells would precede CD40L expression by activated T cells. Activation of NK cells contributes to robust $\mathrm{Th} 1$ responses ${ }^{40-42}$, and more recently, IFN $\gamma$ release by activated NK cells was revealed as the mechanism by which an adjuvanted vaccine response enhanced Th1 responses ${ }^{43}$. Furthermore, crosstalk between NK cells and DCs has been previously identified as a key mechanism through which both populations are fully activated ${ }^{44}$. To investigate early innate cell production of IFN $\gamma$ in vivo, GS mice were infected with $L m-2 \mathrm{~W} 1 \mathrm{~S}$ and assessed $24 \mathrm{~h}$ later. Gating on NK cells revealed substantial IFN $\gamma$ expression compared to NK cells from uninfected GS control mice (Fig. 4c, d). Moreover, NK cells were the dominant source (approximately 70\%) of IFN $\gamma$ expression at this time, with $\mathrm{T}$ cells contributing most of the remaining signal (Fig. 4e, f). To ask whether this early IFN $\gamma$ signal was required for upregulation of OX40L on DCs, wildtype (WT) and IFN $\gamma^{-1-}$ mice were infected with $L m-2 \mathrm{~W} 1 \mathrm{~S}$ and DC expression of OX40L assessed $24 \mathrm{~h}$ later. Notably, the upregulation of OX40L expression by DCs isolated from IFN $\gamma^{-I-}$ mice was impeded compared to WT controls but was higher than the basal level observed in uninfected mice (Fig. 4g). These data indicate that early IFN $\gamma$ was resulting in the increase in OX40L expression by DCs, but other signals might also contribute. In vitro, Th1 responses to heat-killed $\mathrm{Lm}$ required IL-12 45,46 , and neutralisation of IL-12 in vivo results in reduced resistance to $L m$, which could be reversed by recombinant IFN $\gamma^{47}$. To assess the requirement for IL-12, IL-12p35 $35^{-1-}$ mice were infected with $L m-2 \mathrm{~W} 1 \mathrm{~S}$ and assessed $24 \mathrm{~h}$ later for NK cell production of IFN $\gamma$ and OX40L expression by splenic DCs. The 
a

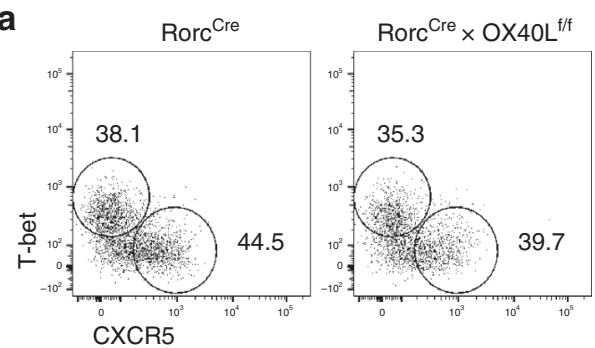

d

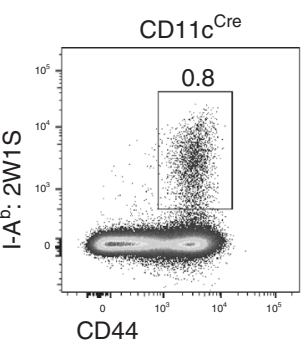

f
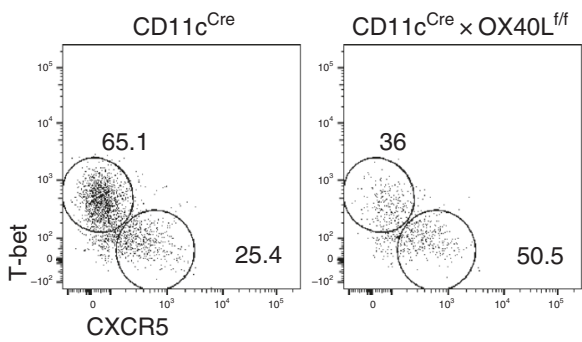

h
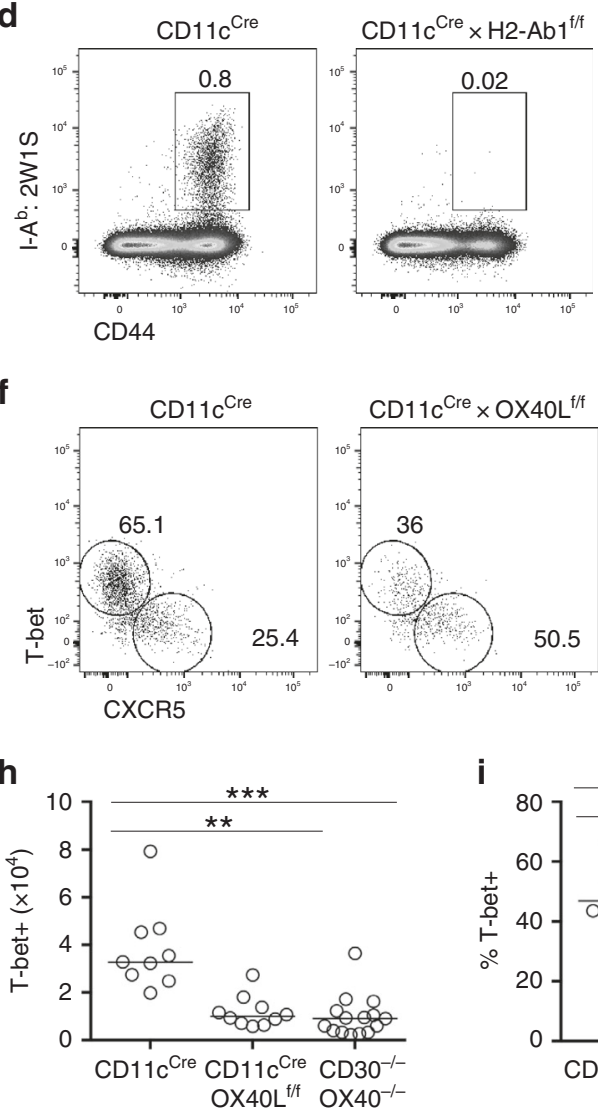

i b
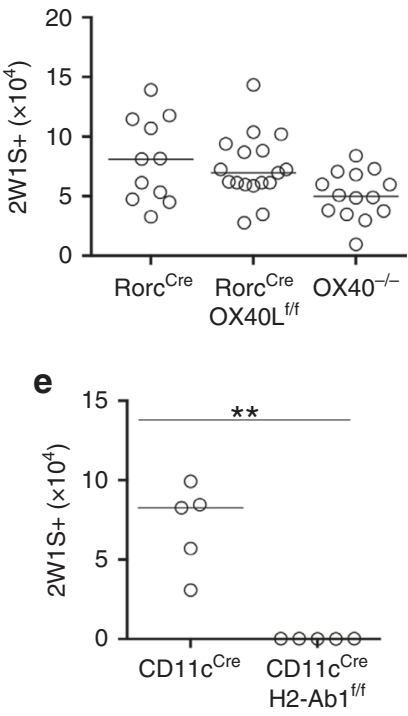

c

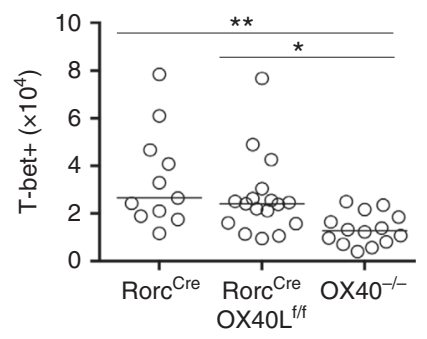

$\mathrm{g}$
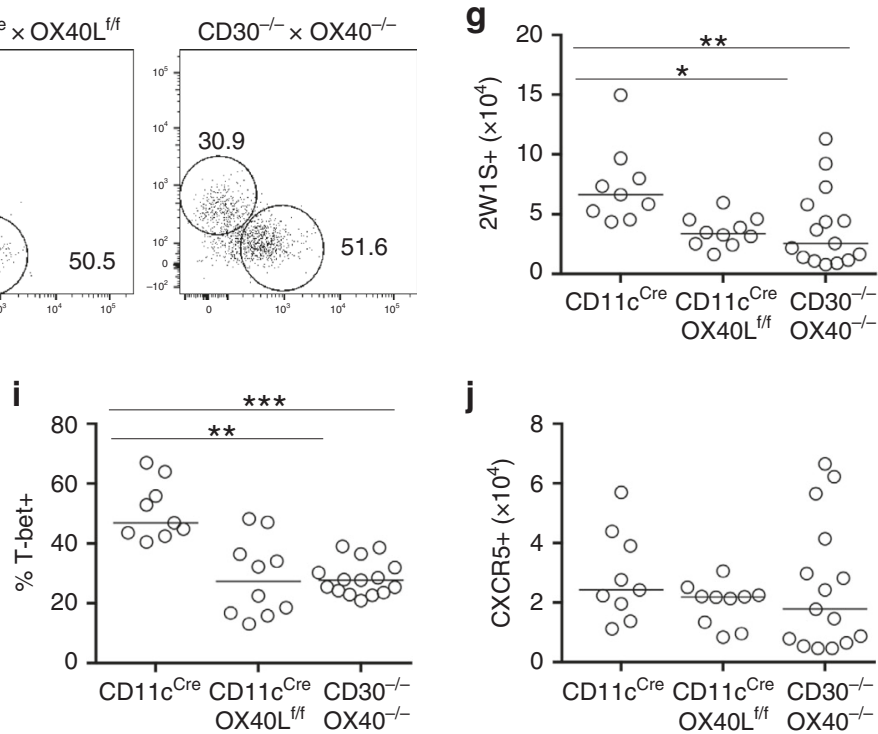

j

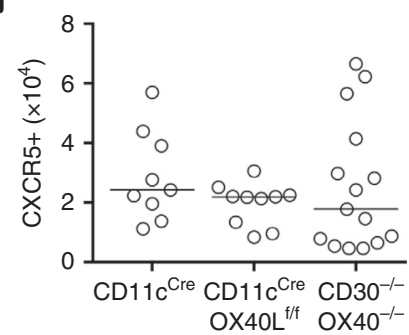

Fig. 3 Expression of OX40L by DC is required for effector Th1 responses. To investigate the critical cellular interaction for generation of Th1 effector T cells, conditional OX40L-deficient mice targeting ILC3s (Rorc ${ }^{\text {cre }}$ ) or DCS (CD11c cre) were generated. a Expression of T-bet versus CXCR5 by 2W1S-

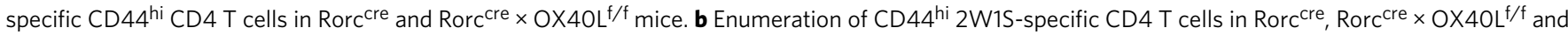

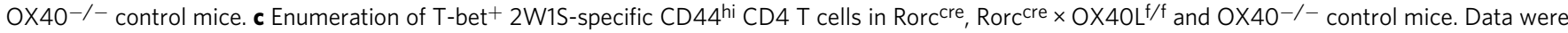
pooled from 3 independent experiments ( $n=11$ Rorc ${ }^{\text {cre }}$ mice, $n=17$ Rorc ${ }^{\text {cre }} \times O_{X} 40 L^{\mathrm{f} / f}$ mice, $n=14$ OX $40^{-/-}$mice). d Representative flow cytometric plots showing CD44hi 2W1S-specific CD4 T cells in the spleen of CD11c cre and CD11cre $\times \mathrm{H} 2-\mathrm{Ab} 1^{\mathrm{f} / \mathrm{f}}$ mice at 7 days post infection. e Enumeration of CD44hi 2W1S-specific CD4 T cells. Data are representative of 2 independent experiments, $n=5$ mice per group. $\mathbf{f}$ Expression of T-bet versus CXCR5 by 2 W1Sspecific CD44 hi CD4 T cells in CD11c cre, CD11c cre $\times$ OX40L f/f and CD30-/- $\times$ OX40-/- mice. g Enumeration of 2W1S-specific CD44hi CD4 T cells. h Enumeration of T-bet ${ }^{+}$2W1S-specific CD44hi CD4 T cells. i Percentage of 2W1S-specific CD4 T cells expressing T-bet. $\mathbf{j}$ Enumeration of CXCR5 ${ }^{+}$ 2W1S-specific CD44hi CD4 T cells. Data were pooled from 3 independent experiments $\left(n=9 \mathrm{CD} 11 \mathrm{c}^{\mathrm{cre}}\right.$ mice, $n=10 \mathrm{CD} 11 \mathrm{c}^{\mathrm{cre}} \times \mathrm{OX} 40 \mathrm{~L}{ }^{\mathrm{f} / \mathrm{f}} \mathrm{mice}, n=15$ $\mathrm{CD} 30^{-/-} \times \mathrm{OX} 40^{-/-}$mice). Values on flow cytometric plots represent percentages; bars on scatter plots represents the median. Statistical significance was tested in e by using an unpaired, non-parametric, Mann-Whitney two-tailed $T$ test and in $\mathbf{b}, \mathbf{c}, \mathbf{h}$-j by using Kruskal-Wallis one-way ANOVA with post hoc Dunn's test: ${ }^{\star} p \leq 0.05,{ }^{\star \star} p \leq 0.01,{ }^{\star \star \star} p \leq 0.001$.

proportion of NK cells producing IFN $\gamma$ (Fig. 4h, i) and the amount of IFN $\gamma$ produced (Fig. $4 \mathrm{j}$ ) were significantly reduced in IL-12p35-I- mice and DC upregulation of OX40L was impaired (Fig. 4k, 1), indicating that IL-12-mediated NK cell expression of IFN $\gamma$ was linked to DC OX40L expression. We further confirmed that expression of IL-12 mRNA was equally upregulated by DCs from CD $11 c^{\text {cre }} \times O \mathrm{OX}_{40 \mathrm{~L}} \mathrm{f} / \mathrm{f}$ and $\mathrm{OX} 40 \mathrm{~L}^{\mathrm{f} / \mathrm{f}}$ littermate controls after infection with $\mathrm{Lm}-2 \mathrm{~W} 1 \mathrm{~S}$ (Supplementary Fig. 4), indicating that IL-12 production by
OX40L-deficient DCs was not impaired and the loss of Th1 effector cells not due to impaired polarisation during priming.

Since the activation of NK cells can occur subsequent to the rapid activation of invariant $\mathrm{NK} \mathrm{T}$ (iNKT) cells and mediated through very early iNKT expression of IFN $\gamma^{48}$, we assessed the requirement for iNKT cell activation using $\mathrm{CD} 1 \mathrm{~d}^{-1-}$ mice. WT, CD1d ${ }^{-1-}$ and IFN $\gamma^{-/-}$mice were infected with $L m-2 \mathrm{~W} 1 \mathrm{~S}$, and $\mathrm{NK}$ cell IFN $\gamma$ expression was assessed $24 \mathrm{~h}$ later. NK cells from

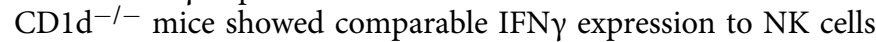


a

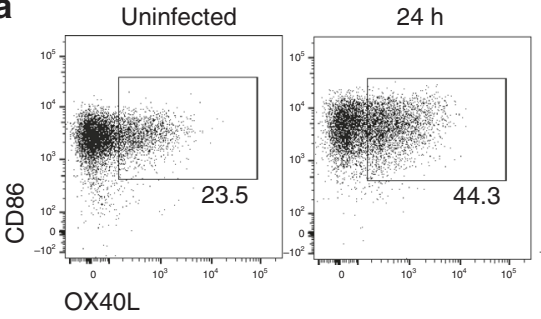

$48 \mathrm{~h}$

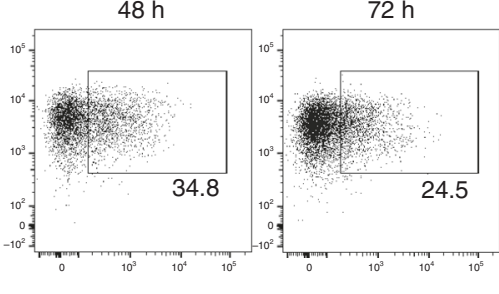

b

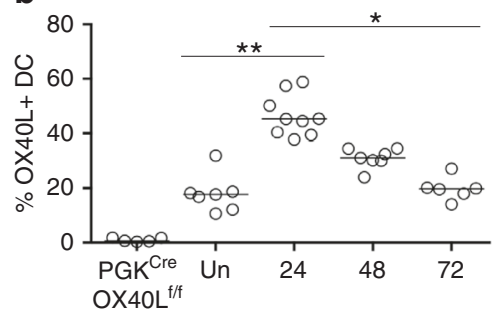

C

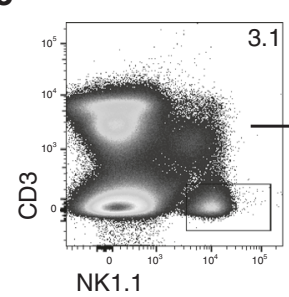

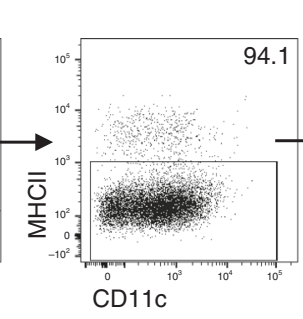

CD11c

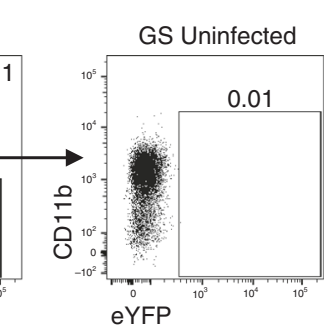

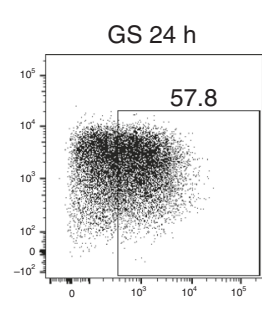

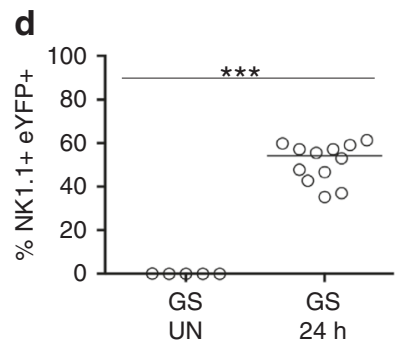

e

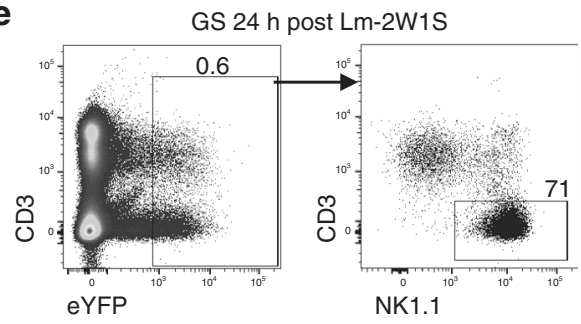

f

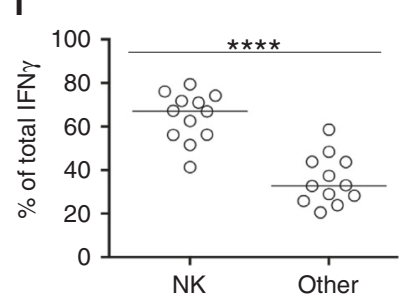

g

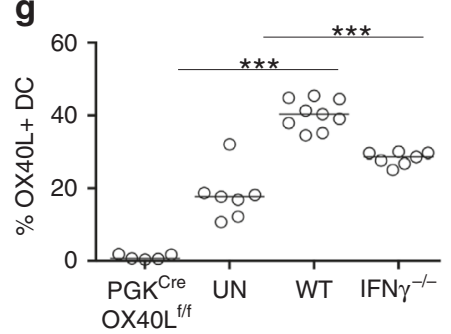

h

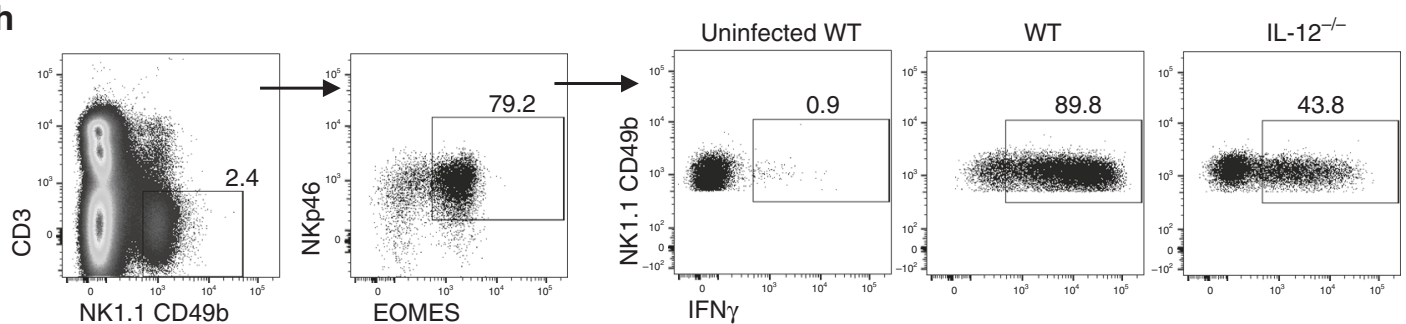

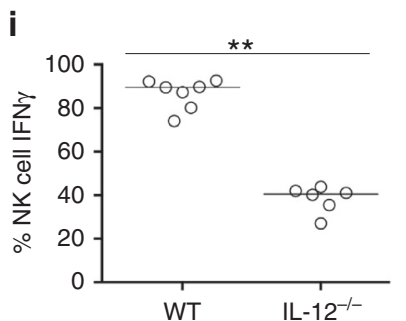

j

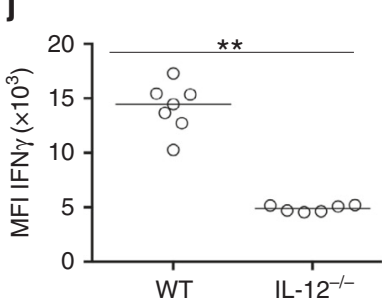

m

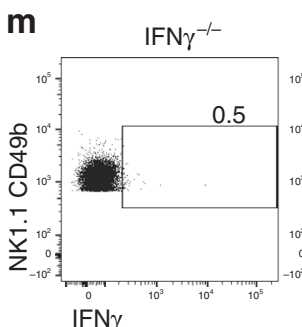

WT
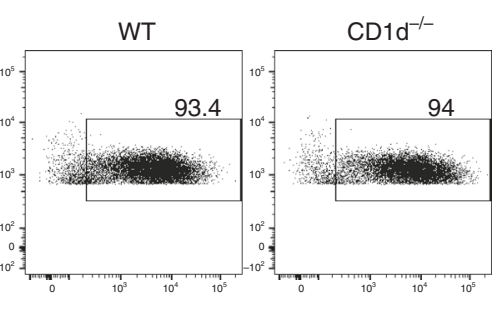

from WT controls (Fig. 4m, n). Furthermore, DC expression of OX40L was also not impaired in $\mathrm{CD}^{-1-}$ mice (Fig. 4o). Combined, these data reveal that iNKT cells are not required for IFN $\gamma$ production by $\mathrm{NK}$ cells in response to $L m-2 \mathrm{~W} 1 \mathrm{~S}$ and highlight the importance of IFN $\gamma$ in enhancing DC expression of OX40L.
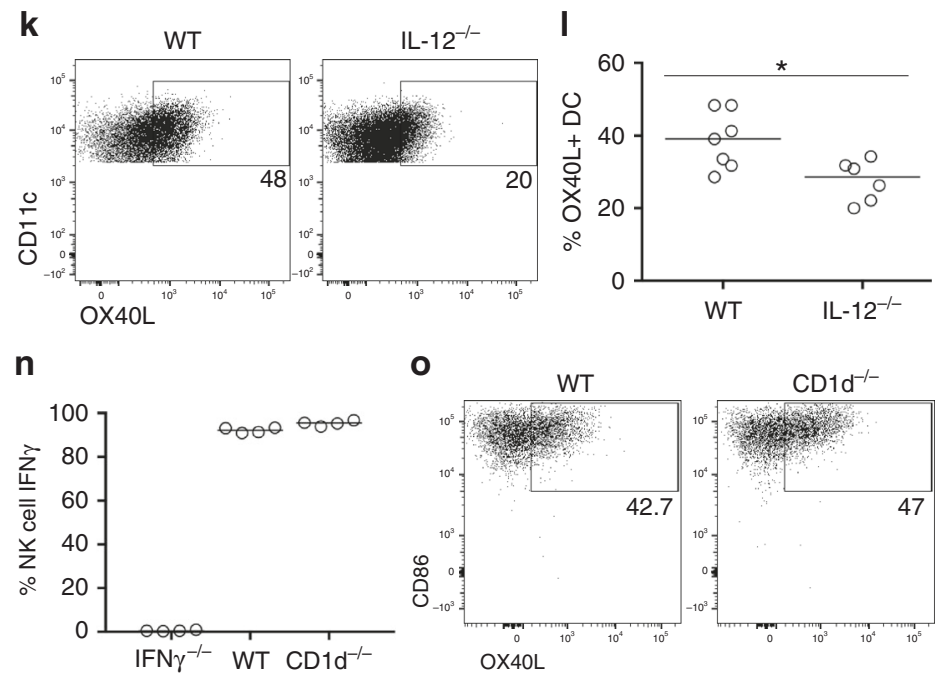
Fig. 4 OX40L is upregulated on DCs in response to IL-12-mediated production of IFN $\boldsymbol{\gamma}$ by NK cells. Splenocytes were isolated from mice at different times post infection with $\mathrm{Lm}-2 \mathrm{~W} 1 \mathrm{~S}$. a Expression of OX4OL by DC (lin ${ }^{-}(\mathrm{CD} 3, \mathrm{~B} 220, \mathrm{CD} 49 \mathrm{~b}), \mathrm{CD} 11 \mathrm{c}^{+}, \mathrm{MHCII}^{+}, \mathrm{CD}^{2} 6^{+}$, SIRP $\alpha^{+}$) from uninfected mice and mice infected with $L m-2 W 1 S 24,48$ and $72 \mathrm{~h}$ previously. b Proportion of DC-expressing OX4OL at different times post infection with $L m-2 \mathrm{~W} 1 \mathrm{~S}$, versus

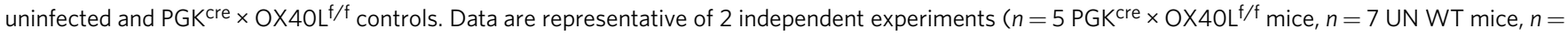
$9 \mathrm{WT}$ mice at $24 \mathrm{~h}$ post $L m-2 \mathrm{~W} 1 \mathrm{~S}, n=7 \mathrm{WT}$ mice at $48 \mathrm{~h}$ post $L m-2 \mathrm{~W} 1 \mathrm{~S}, \mathrm{n}=6 \mathrm{WT}$ mice at $72 \mathrm{~h}$ post $L m-2 \mathrm{~W} 1 \mathrm{~S}$ infection). Great $\times$ Smart17A mice were used to assess IFN $\gamma$ production at $24 \mathrm{~h}$ post infection. $\mathbf{c}$ Representative flow cytometric plots showing the expression of IFN $\gamma$ by NK cells. $\mathbf{d}$ Percentage of NK cells expressing IFN $\gamma$ (eYFP). e Representative flow cytometric plots showing the expression of IFN $\gamma$ by different immune cells. $\mathbf{f}$ Percentage of total IFN $\gamma$ attributable to NK cells or other immune cell populations. Data were pooled from 2 independent experiments $(n=5 \mathrm{GS}$ UN mice, $n=12$ GS mice at 24 post $L m-2 \mathrm{~W} 1 \mathrm{~S}$ ). $\mathbf{g}$ Splenocytes from WT and IFN $\gamma^{-/-}$mice were assessed for OX4OL expression at $24 \mathrm{~h}$ post infection with $\mathrm{Lm}-2 \mathrm{~W} 1 \mathrm{~S}$, alongside $P \mathrm{PK}^{\mathrm{cre}} \times \mathrm{OX} 4 \mathrm{OL}^{\mathrm{f} / \mathrm{f}}$ and uninfected $(\mathrm{UN})$ controls. Data were pooled from 2 independent experiments $\left(n=5 \mathrm{PGK}\right.$ cre $\times O X 40 L^{\mathrm{f} / \mathrm{f}} \mathrm{mice}, n=7 \mathrm{UN}$ WT mice, $n=9 \mathrm{WT}$ mice, $n=7 \mathrm{IFN} \gamma^{-/-}$mice). $\mathbf{h}$ Representative flow cytometric plots showing production of IFN $\gamma$ by NK cells from uninfected WT and infected WT and IL-12p35- $/-$ mice $24 \mathrm{~h}$ post $L m-2 \mathrm{~W} 1 \mathrm{~S}$. i, $\mathbf{j}$ Proportion of NK cells producing IFN $\gamma$ and MFI of IFN $24 \mathrm{~h}$ post infection with $\mathrm{Lm}-2 \mathrm{~W} 1 \mathrm{~S}$. $\mathbf{k}$ Representative flow cytometric plots showing OX40L expression on DC in WT and IL-12p35-/- mice $24 \mathrm{~h}$ post infection with $\mathrm{Lm}$-2W1S. I Percentage of DC-expressing OX4OL in WT and IL-12p35-/- mice $24 \mathrm{~h}$ post infection with $\mathrm{Lm}-2 \mathrm{~W} 1 \mathrm{~S}$. Data are representative of 1 experiment $\left(n=7 \mathrm{WT}\right.$ mice, $n=6 \mathrm{IL}-12 \mathrm{p} 35^{-/}-$mice $)$. m Representative flow cytometric plots showing the expression of IFN $\gamma$ by splenic NK cells from IFN $\gamma^{-/-}$, WT and CD1d ${ }^{-/-}$mice $24 \mathrm{~h}$ after infection with Lm-2W1S. $\mathbf{n}$ Percentage of NK cells expressing IFN $\gamma$. o Expression of OX4OL by DC from WT and CD1d ${ }^{-/-}$mice $24 \mathrm{~h}$ after infection with $L m-2 \mathrm{~W} 1 \mathrm{~S}$. Data are representative of 1 experiment ( $n=4$ mice per group). Values on flow cytometric plots represent percentages; bars on scatter plots represents the median. Statistical significance was tested in $\mathbf{b}, \mathbf{g}$ by using Kruskal-Wallis one-way ANOVA with post hoc Dunn's test and in $\mathbf{d}, \mathbf{i}, \mathbf{j}, \mathbf{I}$ by using an unpaired, non-parametric, Mann-Whitney two tailed $T$ test: ${ }^{\star} p \leq 0.05,{ }^{\star \star} p \leq 0.01,{ }^{\star \star \star} p \leq 0.001,{ }^{\star \star \star \star} p \leq 0.0001$.

a

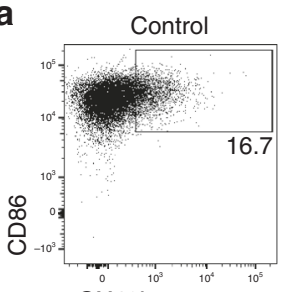

OX40L

C
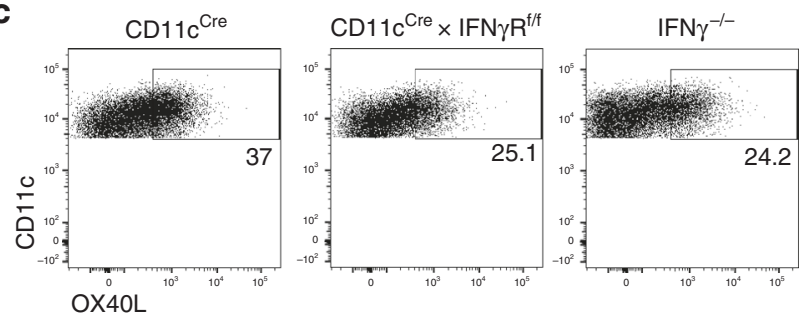

$\mathrm{IFN} \gamma$

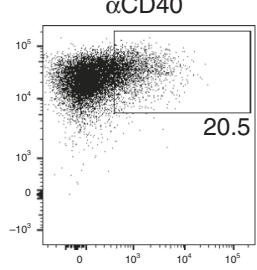

20.5

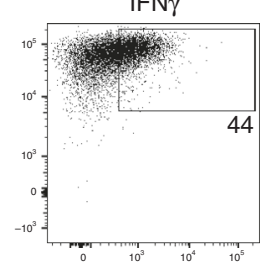

b

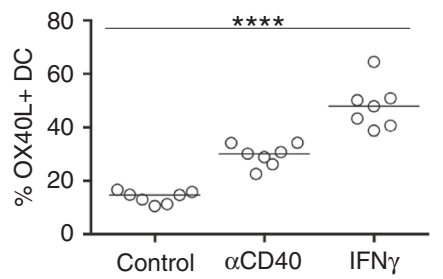

d

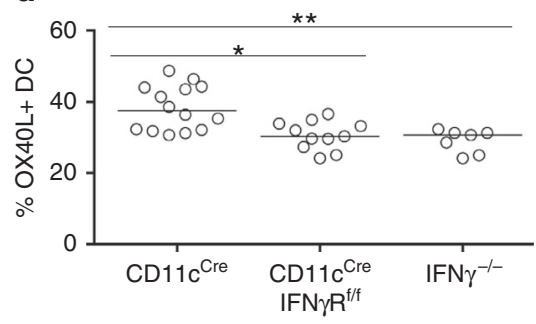

e

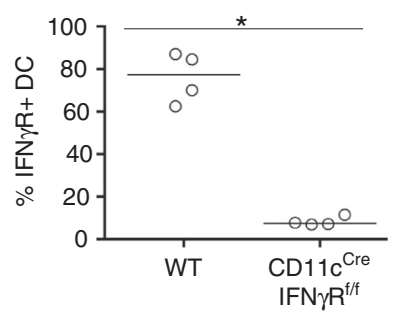

f

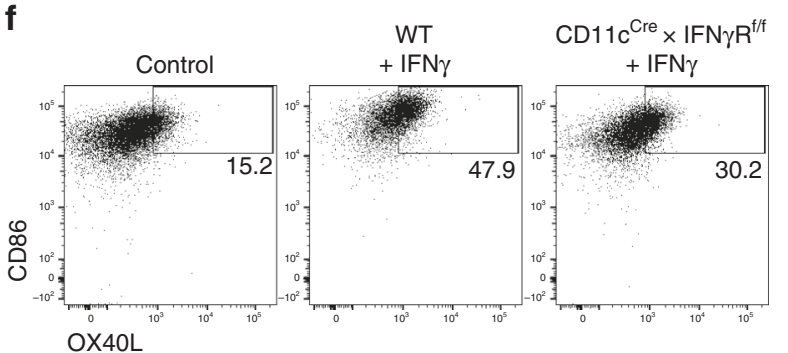

g

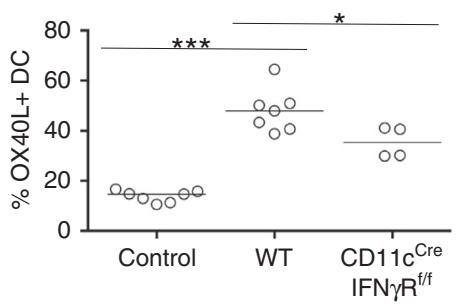

Fig. 5 IFN $\gamma$ directly enhances OX40L expression on DCs. To determine the mechanism of how IFN $\gamma$ caused the upregulation of OX4OL on DCs, in vitro and in vivo experiments to test a direct interaction were performed. a Representative flow cytometric plots showing the expression of OX4OL by splenic DCs cultured with either anti-CD40 Abs or recombinant IFN $\gamma$. b Percentage of DC-expressing OX40L after culture. Data were pooled from 2 independent experiments, $n=7$. c Representative flow cytometric plots showing the expression of OX4OL on DCs from CD11c Cre, CD11c Cre $\times I F N \gamma \mathrm{R}^{\mathrm{f} / \mathrm{f}}$ and IFN $\gamma^{-/-}$mice $24 \mathrm{~h}$ after infection with $\mathrm{Lm}-2 \mathrm{~W} 1 \mathrm{~S}$. d Proportion of DC-expressing OX4OL $24 \mathrm{~h}$ post infection with $\mathrm{Lm}-2 \mathrm{~W} 1 \mathrm{~S}$. Data are representative of 3 independent experiments $\left(n=14 \mathrm{CD} 11 c^{\mathrm{Cre}}\right.$ mice, $n=11 \mathrm{CD} 11 \mathrm{c} C \mathrm{Cre} \times \mathrm{IFN} \gamma \mathrm{R}^{\mathrm{f} / \mathrm{f}}$ mice, $n=7 \mathrm{IFN} \gamma^{-/}-$mice) . e Proportion of DC-expressing IFN $\gamma \mathrm{R}$ in WT versus CD11c $\mathrm{Cre} \times$

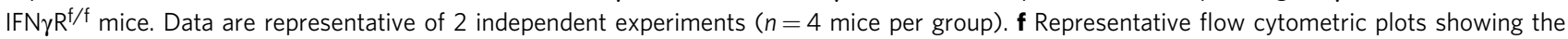
expression of OX4OL by DCs isolated from WT versus CD11c Cre $\times I F N \gamma R^{\mathrm{f} / \mathrm{f}}$ mice and cultured with recombinant IFN $\gamma$. $\mathbf{g}$ Proportion of DC-expressing OX4OL after culture with recombinant IFN . Data are representative of 2 independent experiments $\left(n=7 \mathrm{WT}\right.$ mice, $n=4 \mathrm{CD} 11 \mathrm{c} C \mathrm{Cr} \times \mathrm{IFN} \gamma \mathrm{R}^{\mathrm{f} / \mathrm{f}}$ mice). Values on flow cytometric plots represent percentages; bars on scatter plots represents the median. Statistical significance was tested in $\mathbf{b}$, $\mathbf{d}$ by using Kruskal-Wallis one-way ANOVA with post hoc Dunn's test and in $\mathbf{e}, \mathbf{g}$ by using an unpaired, non-parametric, Mann-Whitney two-tailed $T$ test: ${ }^{\star} p \leq 0.05$, ${ }^{\star *} p \leq 0.01,{ }^{* \star *} p \leq 0.001,{ }^{* \star *} p \leq 0.0001$. 
directly stimulate OX40L expression via signals through the IFN $\gamma$ R. To test this in vivo, CD $11 c^{\text {cre }} \times \operatorname{IFN} \gamma \mathrm{R}^{\mathrm{f} / \mathrm{f}}$ mice were generated and infected with $L m-2 \mathrm{~W} 1 \mathrm{~S}$ alongside $\mathrm{CD} 11 \mathrm{c}^{\mathrm{cre}}$ and IFN $\gamma^{-l-}$ controls. DCs isolated from either CD $11 c^{c r e} \times \operatorname{IFN} \gamma \mathrm{R}^{\mathrm{f} / \mathrm{f}}$ or total IFN $\gamma^{-1-}$ mice expressed significantly less OX40L than controls (Fig. 5c, d). Flow cytometric analysis of IFN $\gamma$ R expression by $\mathrm{CD}_{11 \mathrm{c}^{+}}$DCs confirmed efficient deletion of this receptor in $\mathrm{CD} 11 \mathrm{c}^{\text {cre }} \times \mathrm{IFN} \gamma \mathrm{R}^{\mathrm{f} / \mathrm{f}}$ mice (Fig. 5e). Finally, DCs from $\mathrm{CD} 11 \mathrm{c}^{\mathrm{cre}} \times \mathrm{IFN} \gamma \mathrm{R}^{\mathrm{f} / \mathrm{f}}$ mice cultured with recombinant IFN $\gamma$ failed to upregulate OX40L to the level observed for WT controls (Fig. 5f, g). Combined, these data indicate a mechanism where DC-expressed IL-12 instructs NK production of IFN $\gamma$, which then directly signals back to the DC to enhance OX40L expression and orchestrate the generation of a robust Th1 effector T cell response.

Although $\mathrm{NK}$ cells were the largest population of IFN $\gamma^{-}$ expressing cells, $\mathrm{CD}^{+} \mathrm{IFN}^{+}$cells were evident $24 \mathrm{~h}$ after infection with $L m-2 \mathrm{~W} 1 \mathrm{~S}$ raising the possibility that multiple sources of IFN $\gamma$ expression contributed to DC activation. To better understand the spatial distribution of IFN $\gamma$-producing cells in the spleen after $L m$ infection, IFN $\gamma$ expression was localised in tissue sections $24 \mathrm{~h}$ post infection. Expression of IFN $\gamma$ was detected within some white pulp areas of the spleen of infected mice (Supplementary Fig. 5). Both IFN $\gamma^{+} \mathrm{NK}$ cells and IFN $\gamma^{+}$ CD8 $\mathrm{T}$ cells were detected in approximately equal frequency in the proximity of DCs in the splenic white pulp (Fig. 6a, b). To specifically test in vivo whether NK cells were a critical source of IFN $\gamma$, mice were treated with either anti-NK1.1 Abs alone or in combination with anti-CD8 Abs, then infected with Lm-2W1S and analysed $24 \mathrm{~h}$ later. Depletion of the targeted cells and a loss IFN $\gamma$ expression among this population was confirmed by flow cytometry (Supplementary Fig. 6), and the expected reduction in IFN $\gamma$ expression was observed when splenocytes were analysed after ex vivo culture in the presence of brefeldin A (Fig. 6c-e). Importantly, depletion of $\mathrm{NK}$ cells resulted in the impaired upregulation of OX40L expression by DCs, comparable to that observed in IFN $\gamma^{-1-}$ controls (Fig. 6f), indicating that NK cells were a critical in vivo source of the cytokine. Given the proximity of IFN $\gamma^{+}$CD8 T cells to DCs in the splenic white pulp of $\mathrm{Lm}$ $2 \mathrm{~W} 1 \mathrm{~S}$-infected mice, mice were also treated with a combination of anti-NK1.1 and anti-CD8 Abs; however, this did not significantly reduce the OX40L expression by DCs further.

While our data indicated an important role for IFN $\gamma$ in regulating OX40L expression, the OX40L expression by DC when IFN $\gamma$ signalling was disrupted remained higher than in uninfected mice, indicating that other signals likely contributed to the upregulation of this ligand. To investigate this further, we employed in vitro cultures of splenocytes to screen other cytokines that could boost the expression of OX40L by DCs. Splenocytes from WT and IFN $\gamma^{-1-}$ mice were compared in parallel to help determine potentially indirect effects via stimulating IFN $\gamma$ expression in the cultures. Notably, basal expression of OX40L in IFN $\gamma^{-1-}$ splenocyte cultures was lower than in WT controls. Recombinant IFN $\gamma$ robustly upregulated OX40L expression as observed previously, but both IL-18 and TNFa were identified as further cytokines that could enhance OX40L expression by DCs in this assay (Supplementary Fig. 7).

NK cell-derived IFN $\gamma$ upregulates OX40L on human DCs. Having identified how DC expression of OX40L in response to $\mathrm{Lm}-2 \mathrm{~W} 1 \mathrm{~S}$ infection was controlled in vivo, we sought to confirm that this pathway was conserved in human DCs. Human cDC2 were isolated to high purity by fluorescence-activated cell sorting (FACS) and then cultured alone or with autologous FACSisolated NK cells (Supplementary Fig. 8). Under these conditions, recombinant human IFN $\gamma$ was sufficient to significantly enhance OX40L expression consistent with direct effects of this cytokine on human $\mathrm{cDC} 2$ (Fig. 7a-c). Activation of NK cells in co-culture with $\mathrm{CDC} 2$ through addition of IL-12 and IL-15 was also able to enhance OX40L expression to similar levels as the recombinant IFN $\gamma$. Thus the mechanism of direct IFN $\gamma$ signalling to DCs resulting from crosstalk with $\mathrm{NK}$ cells would also appear to operate for human DCs.

DC expression of OX40L redundant in intestinal Th1 response. Our data have revealed that OX40L expression by DCs, licenced by early crosstalk with NK cells, is sufficient for Th1 cell expansion and function in a model of acute systemic bacterial infection. To ask whether this mechanism was specific to the splenic response observed with $L m-2 \mathrm{~W} 1 \mathrm{~S}$ infection, we sought to test the requirement for DC OX40L under quite different experimental conditions. To this end, we established an oral Salmonella infection model using an attenuated Salmonella2W1S strain ${ }^{49}$, thus enabling tracking of the same endogenous 2W1S-specific CD4 T cell response within the draining secondary lymphoid tissue (mesenteric LNs (mLNs)) and the non-lymphoid effector site (colon). Having established that OX40L expression by ILC3s was not required in the response to $L m-2 \mathrm{~W} 1 \mathrm{~S}$, the Salmonella infection model provided an opportunity to further test the potential role of ILC3s in supporting CD4 T cells at mucosal sites via their expression of OX40L ${ }^{50}$. Thus CD11 $c^{\text {cre }} \times$ $\mathrm{OX} 40 \mathrm{~L}^{\mathrm{f} / \mathrm{f}}$ and Rorc ${ }^{\text {cre }} \times \mathrm{OX} 40 \mathrm{~L}^{\mathrm{f} / \mathrm{f}}$ mice, alongside littermate OX40L $\mathrm{L}^{\mathrm{f}} \mathrm{f}$ only and OX40-deficient controls, were infected, and the $2 \mathrm{~W} 1 \mathrm{~S}$-specific response was assessed 7 days later in the colon (Fig. 8a). To aid assessment of cytokine production, the different OX40L conditional mice had been further crossed with Great $x$ Smart17A dual IFN $\gamma$ and IL-17A reporters. Enumeration of the total CD4 $\mathrm{T}$ cell response confirmed a significant reduction in the intestinal CD4 $\mathrm{T}$ cell compartment in mice lacking OX40 (Fig. 8 b $)^{51}$, which was not detected in the conditional OX40Ldeficient mice. Strikingly, the number of 2W1S-specific CD4 $\mathrm{T}$ cells, alongside the proportion and number of IFN $\gamma^{+}\left(\mathrm{eYFP}^{+}\right)$, was specifically reduced in $\operatorname{Rorc}^{\mathrm{cre}} \times \mathrm{OX} 40 \mathrm{~L}^{\mathrm{f} / \mathrm{f}}$, but not in $\mathrm{CD} 11 \mathrm{c}^{\mathrm{cre}} \times \mathrm{OX} 40 \mathrm{~L}^{\mathrm{f} / \mathrm{f}}$ mice (Fig. $8 \mathrm{c}-\mathrm{e}$ ), indicating that, for the effector Th1 cells in the colon, OX40L expression by ILC3s rather than by DCs was required. Furthermore, assessment of the response in the $\mathrm{mLN}$ (Fig. $8 \mathrm{f}$ ) again revealed that the $2 \mathrm{~W} 1 \mathrm{~S}$ Th1 response was specifically reduced in $\operatorname{Rorc}^{\text {cre }} \times \mathrm{OX}_{40 \mathrm{~L}} \mathrm{f} / \mathrm{f}$ mice (Fig. 8g-i), suggesting that ILC3s might provide OX40L within the draining lymphoid tissue, either in addition or instead of provision within the colon. Regardless, the data clearly showed that, in the primary response to Salmonella-2W1S, the expression of OX40L by DCs was not required to sustain the effector Th1 response.

Collectively these data demonstrate a critical role for OX40L in supporting the effector Th1 response and that in vivo there are specific cellular providers of these signals dependent on the microenvironment and the response.

\section{Discussion}

Many cells are able to present Ag to $\mathrm{T}$ cells and potentially provide the costimulatory signals critical for optimal responses ${ }^{52}$. This suggests that CD4 T cells may interact with distinct Agpresenting cell populations during the initial stages of the immune response as they move through different microenvironments within secondary lymphoid tissue ${ }^{29}$. However, despite its relevance for understanding how CD4 T cell responses are regulated, such a model has not been tested in vivo. Here we have provided a detailed in vivo dissection of the cellular provision of OX40L for Th1 effector CD4 T cells contrasting an acute 
a

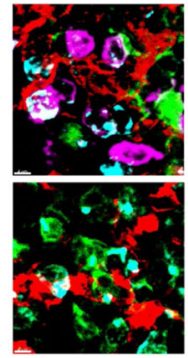

Merge

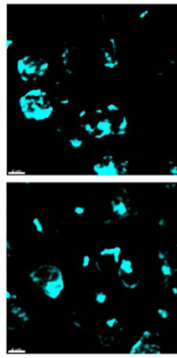

IFN $\gamma$

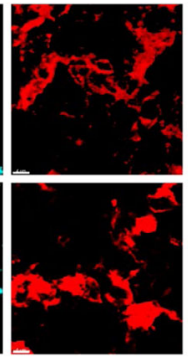

I-A/I-E (Class II)

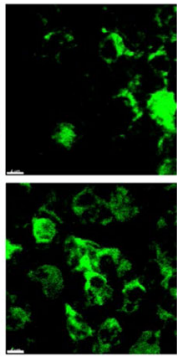

CD8

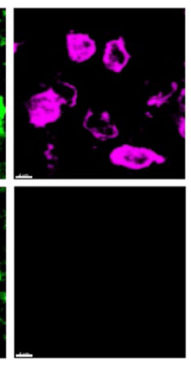

NKp46 b

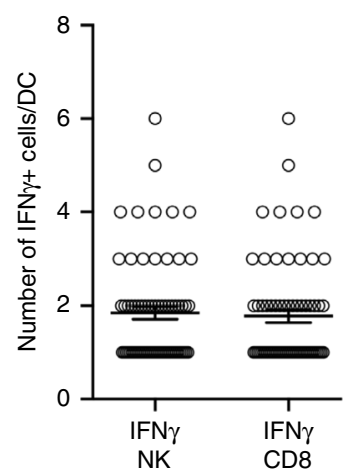

C $\mathrm{IFN} \gamma^{-1-}$

WT
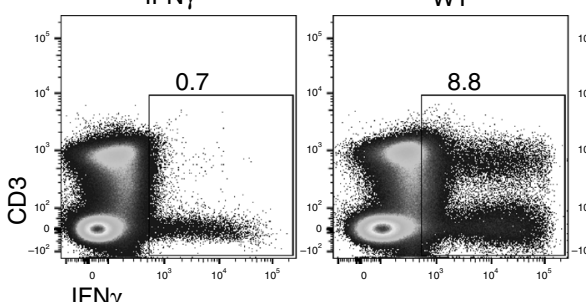

$\alpha \mathrm{NK}$

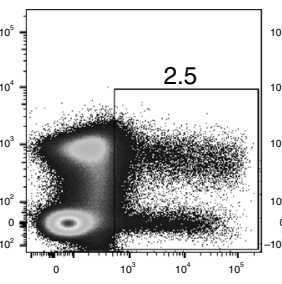

$\alpha N K / C D 8$

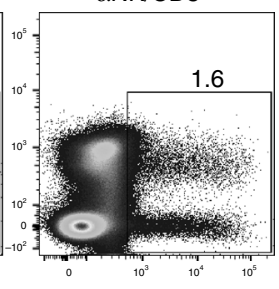

d

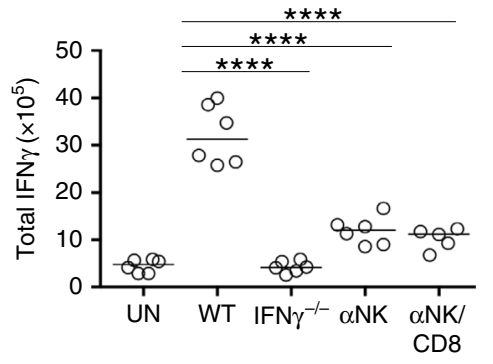

e

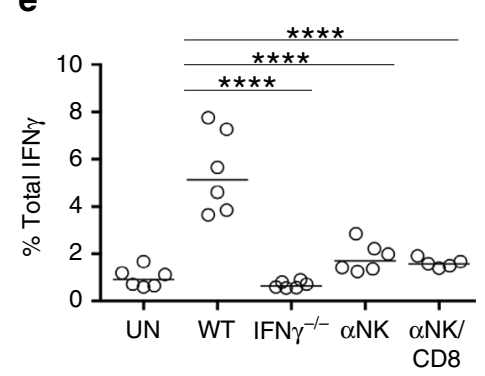

f

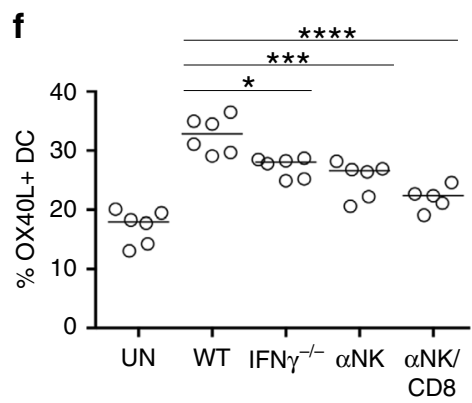

Fig. 6 NK cells are a critical source of IFN $\gamma$ in vivo. To explore the spatial distribution of cells making IFN $\gamma$ after infection with $L m$, WT mice were infected with $L m$ and killed $24 \mathrm{~h}$ after infection (with treatment with brefeldin A $6 \mathrm{~h}$ before spleen harvest). Spleen sections were stained with anti-CD8 (green), Nkp46 (NK, magenta), I-A/I-E (DC, red) and IFN $\gamma$ (cyan) antibodies. a Photographs are representative examples of IFN $\gamma$-producing CD8 and NK cells in close association with dendritic cells, scale bar: $4 \mu \mathrm{m}$. Data are representative of 2 independent experiments. b Quantification of the number of IFN $\gamma$ producing CD8 T cells $(n=67)$ and IFN $\gamma$-producing NK cells $(n=70)$ in contact per dendritic cell $(n=112)$ in 2 different spleens; mean and sem are shown, data were pooled from 2 independent experiments. To investigate the specific role of early IFN $\gamma$ production by NK cells or CD8 T cells, WT mice were given $\alpha$ NK1.1 or $\alpha$ NK1.1 and $\alpha$ CD8 monoclonal antibodies prior to the infection with Lm-2W1S. The IFN $\gamma$ responses and OX4OL expression on DC were assessed $24 \mathrm{~h}$ post infection and were compared to uninfected WT, infected WT and infected IFN $\gamma^{-/-}$mice. c Representative flow cytometric plots showing total production of IFN $\gamma$ at $24 \mathrm{~h}$ post infection. $\mathbf{d}$ Total numbers of IFN $\gamma^{+}$cells. e Percentages of IFN $\gamma^{+}$cells. $\mathbf{f}$ Proportion of dendritic cellexpressing OX4OL at $24 \mathrm{~h}$ post infection. Data were pooled from 2 independent experiments ( $n=6$ UN WT mice, $n=6$ WT mice, $n=6$ IFN $\gamma^{-/-}$mice, $n=6 \alpha$ NK WT mice, $n=5 \alpha$ NK/CD8 WT mice). Statistical significance was tested by using ordinary one-way ANOVA with post hoc Tukey's tests, following successful normality tests: ${ }^{\star} p \leq 0.05,{ }^{\star \star \star} p \leq 0.001,{ }^{\star \star \star \star} p \leq 0.0001$.

systemic response with a chronic intestinal infection. Our data reveal that, in an acute Th1 infection model, OX40L provision by DCs is critical with OX40L expression by T cells, B cells or ILC3s redundant for the Th1 effector $\mathrm{T}$ cell response. In contrast, $\mathrm{DC}$ OX40L expression was not needed for the Th1 effector cells in response to oral Salmonella infection and here OX40L expression by ILC3s, or potentially $\mathrm{T}$ cells, was absolutely required. Thus, through conditionally deleting OX40L on different immune cell populations, our data reveal that, in vivo, there are specific cellular interactions that are critical for normal OX40L provision and this is tissue and response specific.

Having identified that DC expression of OX40L was required for generating a robust Th1 response, we were then able to dissect the pathway through which expression of OX40L by the DC was regulated, thereby identifying that NK cell:DC crosstalk ensures optimal OX40L expression through early IFN $\gamma$ production signalling back to the DC. That this mechanism was also evident for regulating human DC expression of OX40L suggests this is a broadly relevant pathway controlling the expression of this costimulatory molecule. However, it is evident that other proinflammatory cytokines can also enhance DC expression of OX40L and in vitro culture with recombinant IL-18 or TNFa enhanced OX40L expression by DCs and both of these cytokines are required for optimal clearance of virulent $L m$ infection ${ }^{53,54}$. That DC expression of OX40L was critical in the response to $\mathrm{Lm}$ $2 \mathrm{~W} 1 \mathrm{~S}$ likely reflects the very acute nature of this attenuated infection, resulting in only a short window of OX40 expression by activated $\mathrm{T}$ cells and thus presumably limited time for different cellular interactions providing OX40L signals. Where high levels of $\mathrm{Ag}$ are maintained for longer, such as in more chronic infections, T cell expression of OX40 is prolonged and here other cellular interactions after initial DC priming become relevant.

In the response to Salmonella-2W1S, deletion of OX40L using the Rorc $^{\text {cre }}$ resulted in the loss of IFN $\gamma$-producing Th1 CD4 
a

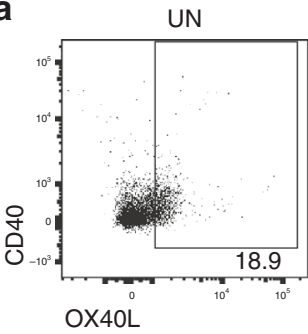

b

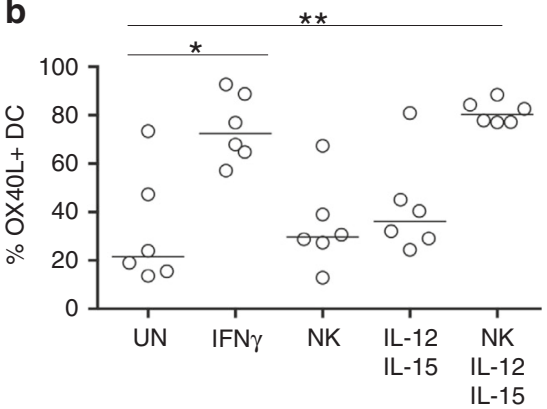

$\mathrm{IFN} \gamma$
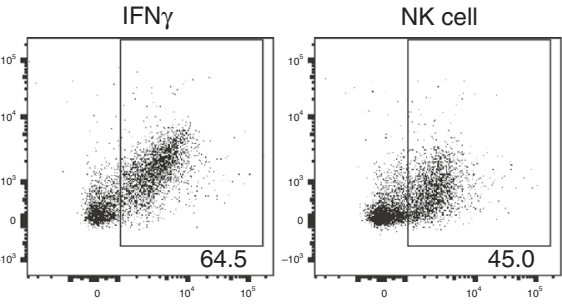

IL-12+IL-15

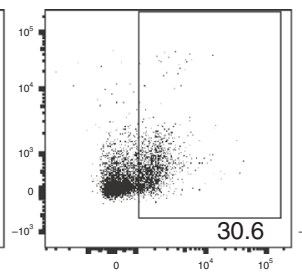

$\mathrm{NK}+\mathrm{IL}-12+\mathrm{IL}-15$

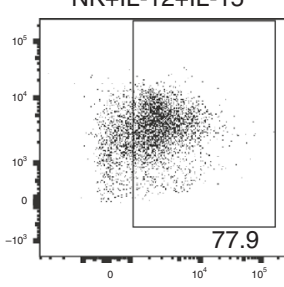

C

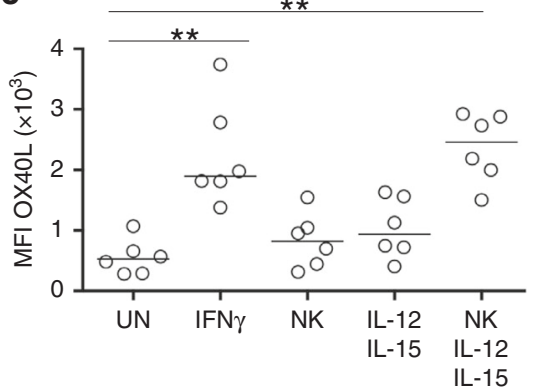

Fig. 7 Human CDC2 upregulate OX40L after treatment with recombinant IFN $\gamma$ or co-culture with autologous NK cells activated by IL-12/15. To investigate whether NK cell crosstalk regulated OX4OL expression on human DCs, CDC2 and NK cells were isolated to high purity by FACS and cultured in vitro. a Representative flow cytometric plots showing the expression of OX4OL and CD40 on cDC2 (CD14- CD19- CD3 $\left.^{-} \mathrm{HLA}^{-} \mathrm{DR}^{+} \mathrm{CD} 1 \mathrm{c}^{+}\right)$after $40 \mathrm{~h}$ of culture in the indicated conditions. $\mathbf{b}$ Percentage of cDC2-expressing OX40L under the conditions indicated. $\mathbf{c}$ MFI of OX4OL expression by $\mathrm{cDC2}$ under the conditions indicated. Data were pooled from 3 independent experiments ( $n=6$ patient samples). Values on flow cytometric plots represent percentages; bars on scatter plots represent the median. Statistical significance was tested by using Kruskal-Wallis one-way ANOVA with post hoc Dunn's test: ${ }^{\star} p \leq 0.05,{ }^{\star \star} p \leq 0.01$.

T cells in both the draining lymphoid tissue and the effector tissue (colon). While $\mathrm{T}$ cell provision of OX40L cannot be excluded, these data are consistent with ILC3 OX40L expression critical for intestinal $\mathrm{T}$ cell responses, significantly developing previous studies using immunodeficient mice ${ }^{50,55}$ where ILC frequencies are grossly perturbed ${ }^{31}$. The lack of a role for ILC3s in the splenic response to $L m-2 \mathrm{~W} 1 \mathrm{~S}$ may reflect the acute response or simply perhaps the very low frequency of ILC3 in the spleen and the lack of clear clusters of ILC3, as seen in the intestine and their draining $\mathrm{LNs}^{30}$. Within the intestinal tract, it is evident that ILC3s restrict responses to commensal bacteria not only at the level of effector $\mathrm{T}$ cell responses ${ }^{56,57}$ but also through $\mathrm{T}$ follicular helper cells and IgA production ${ }^{58}$. Thus ILC3s promote some $\mathrm{T}$ cell responses, while limiting others, indicating a critical regulatory role in intestinal immunity, potentially presenting an attractive cellular target for therapeutic manipulation ${ }^{59}$. Exactly where ILC3s interact with activated T cells remains unanswered; however, the impaired 2W1S-specific response observed in both the mLN and colon suggests a role in the draining lymphoid tissue, and the interfollicular spaces of the mLN may be the critical microenvironment fostering such crosstalk ${ }^{31}$.

The 2W1S-specific CD4 T cell response to Lm-2W1S has been characterised in detail ${ }^{38}$ and contains both T-bet-dependent Th1 effector cells and Bcl-6-dependent follicular $\mathrm{T}$ cells in roughly equal proportions. How the individual cells within this polyclonal response are pushed down one differentiation pathway or another is poorly understood but at least partially reflects differences in the strength of TCR signalling ${ }^{60}$. Our data suggest that only about half the activated CD4 $\mathrm{T}$ cells responding to $L m-2 \mathrm{~W} 1 \mathrm{~S}$ ever express OX40 and differentiate into Th1 effector cells through upregulation of Blimp-1 and T-bet, alongside repression of Bcl$6^{35,61}$. Within the chronic Salmonella model, deletion of OX40L on ILC3 and T cells again resulted in a significant loss in the number Th1 effector cells; however, those cells that survived still expressed IFN $\gamma$. Thus signals through OX40 support Th1 effector cell expansion and survival rather than CD4 T cell differentiation ${ }^{9}$. The central finding of this manuscript is that, depending on the nature of the response, provision of OX40L signals is achieved through quite distinct interactions, with critical contributions by DCs and ILC3 demonstrated in vivo.

Collectively our data reveal that, despite the ability of many cell types to express costimulatory ligands for $\mathrm{T}$ cells, in vivo, there are specific cellular interactions that are needed for provision of these signals. Understanding these regulatory checkpoints and how costimulatory molecule expression is controlled in these situations will present further opportunities to better manipulate $\mathrm{T}$ cell responses for therapeutic benefit.

\section{Methods}

Mice. All mice used were C57BL/6 background and bred at Birmingham, except for IL-12p35 $35^{-I-}$ mice that were generated at the University of Manchester and shipped to Birmingham. Strains used were C57BL/6 (WT), CD11 $c^{\text {cre }}, \mathrm{Cd} 1 \mathrm{~d}^{-1-}$ (JAX stock 017294), E8111 ${ }^{\text {cre62 }}$, Great $\times$ Smart17A $^{36}, \mathrm{H} 2-\mathrm{Ab} 1^{\mathrm{f} / 663}$, IL-12p35 ${ }^{-/-}$ (JAX stock \#002692) $)^{64}$, IFN $\gamma^{-l-}$, IFN $\gamma \mathrm{R}^{\mathrm{f} / \mathrm{f}}(\mathrm{JAX} \text { stock } \# 025394)^{65}, \mathrm{mT} / \mathrm{mG}$ (JAX stock $\# 007576)^{66}, \mathrm{OX}_{40} 0^{-/-}, \mathrm{OX} 40^{-/-} \times \mathrm{CD} 30^{-/-13}, \mathrm{OX} 40 \mathrm{~L}^{\mathrm{f} / \mathrm{f39}}, \mathrm{PGK}^{\mathrm{cre} 67}$ and Rorc ${ }^{\text {cre68 }}$. Animals were used in accordance with Home Office guidelines at the University of Birmingham. Mice were housed at $21^{\circ} \mathrm{C}+/-2{ }^{\circ} \mathrm{C}, 55 \%$ humidity $(+/-10 \%)$ with 12 -h light/dark cycle in 7-7 IVC caging with environmental enrichment of plastic houses plus paper bedding.

Lm-2W1S infection. Mice were infected with $10^{7}$ actA-deficient $L m$-expressing OVA-2W1S ( $L m-2 \mathrm{~W} 1 \mathrm{~S}$, kind gift from Dr. M. Jenkins) through intravenous injection in the tail vein. Bacteria were pre-cultured in $10 \mathrm{ml}$ of LB broth containing $20 \mu \mathrm{g} / \mathrm{ml}$ chloramphenicol from a single colony and grown overnight at $37^{\circ} \mathrm{C}$ at $200-250 \mathrm{rpm}$. Next day, $1 \mathrm{ml}$ of $L m-2 \mathrm{~W} 1 \mathrm{~S}$ was seeded into $200 \mathrm{ml}$ of LB broth containing $20 \mu \mathrm{g} / \mathrm{ml}$ chloramphenicol and grown at $37^{\circ} \mathrm{C}$ at $200-250 \mathrm{rpm}$ until OD600 of $0.6-0.7$ was reached. The liquid bacterial cultures were then centrifuged for $20 \mathrm{~min}$ at $4^{\circ} \mathrm{C}, 4000$ $\mathrm{rpm}$. The supernatant was discarded and pellets were resuspended in LB broth with $15 \%$ glycerol. Glycerol stocks of $L m-2 \mathrm{~W} 1 \mathrm{~S}$ were aliquoted into $1 \mathrm{ml}$ cryovials and stored at $-80^{\circ} \mathrm{C}$. Three randomly chosen samples were used to assess the viability of bacterial stocks by plating serial dilution of bacteria on agar containing $20 \mu \mathrm{g} / \mathrm{ml}$ chloramphenicol. Prior administration, the $1 \mathrm{ml} L m-2 \mathrm{~W} 1 \mathrm{~S}$ was centrifuged and washed with sterile phosphate-buffered saline (PBS) before resuspending in adequate volume of sterile PBS to obtain $10^{7}$ bacteria per $200 \mu$ l. 

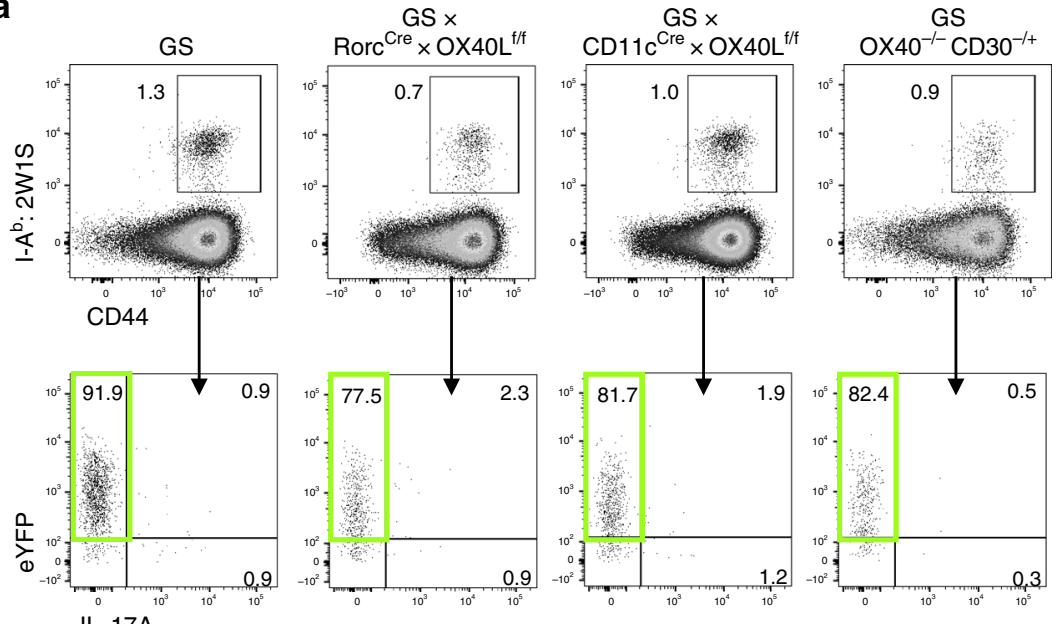

b

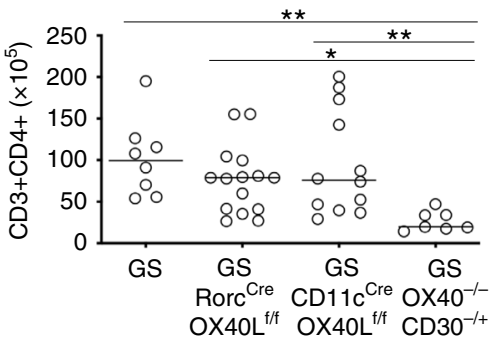

C

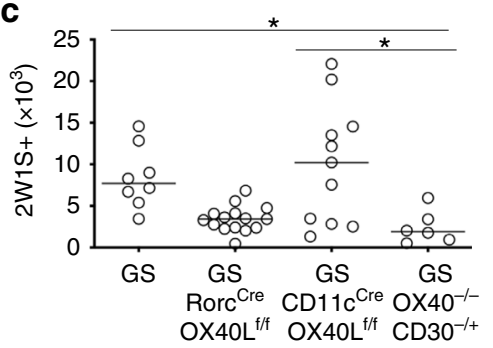

d

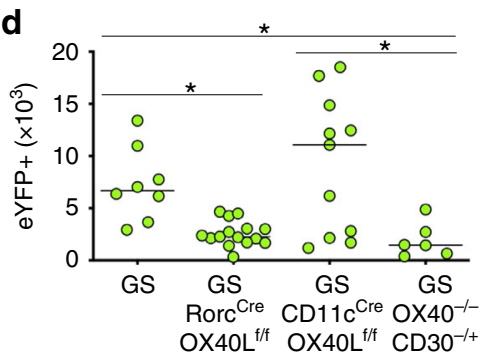

e

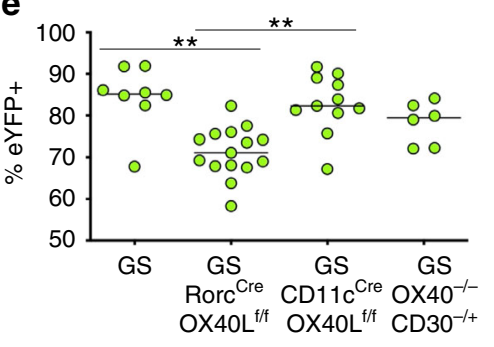

f

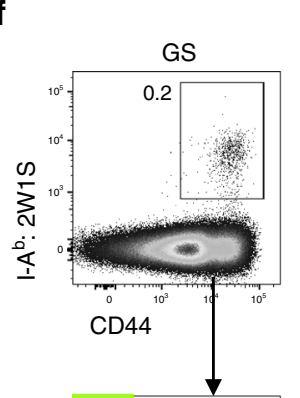

$\sqrt[\operatorname{Rorc}^{\mathrm{GSe}} \times \mathrm{OX}^{2}]{0.1}$

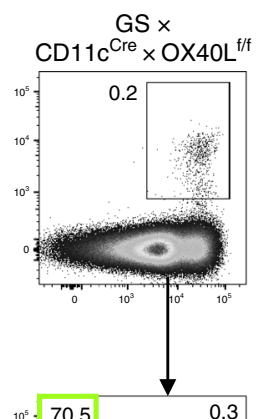

GS
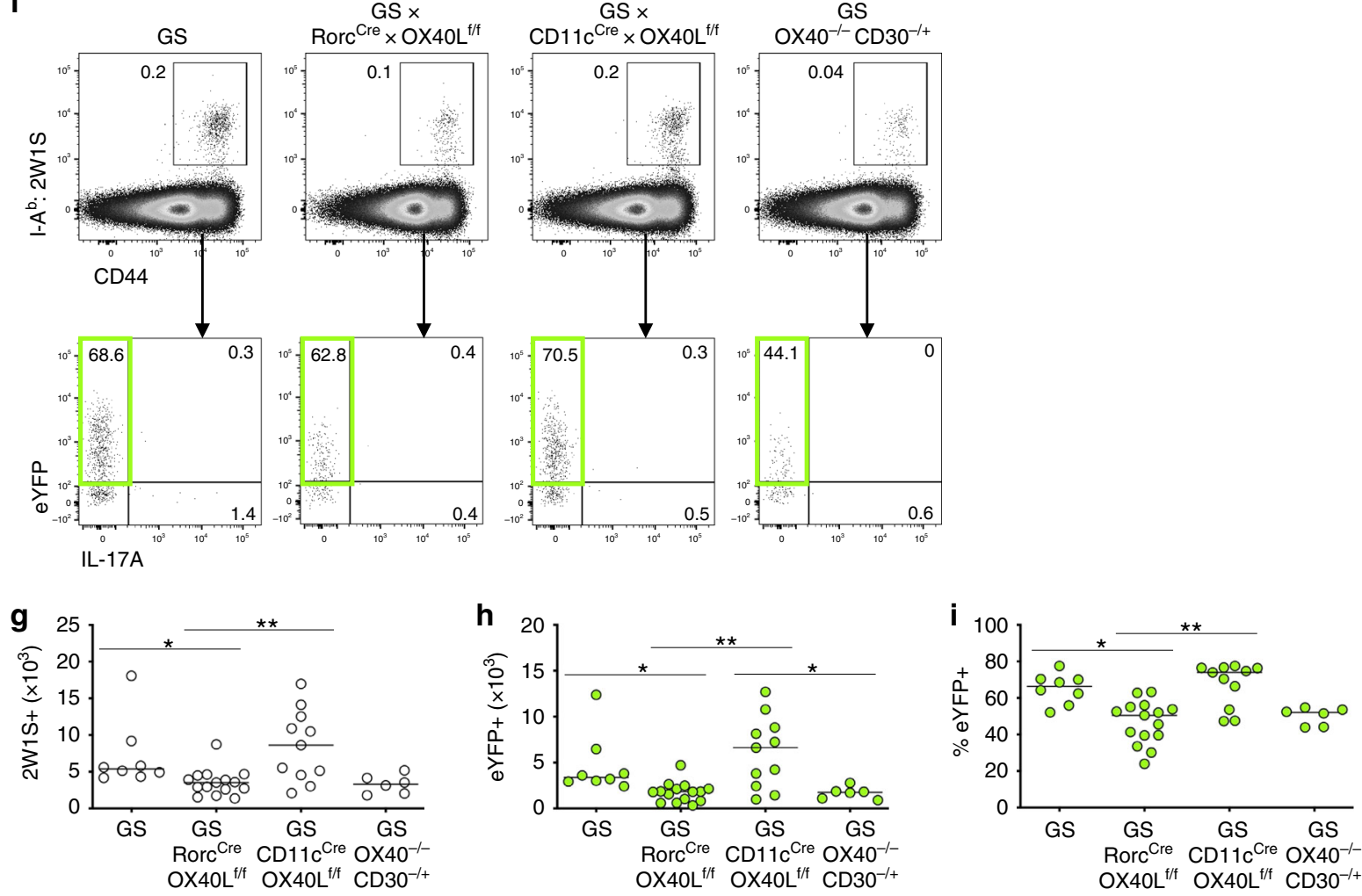

Salmonella-2W1S infection. The mice were given $20 \mathrm{mg}$ of streptomycin (SigmaAldrich) in $100 \mu \mathrm{l}$ sterile PBS by oral gavage $24 \mathrm{~h}$ prior to the administration of Salmonella enterica serovar Typhimurium BRD509 strain expressing the 2W1S epitope $^{49}$ (Salmonella-2W1S, kind gift from Dr. S. McSorley). Bacteria were resuspended in adequate volume of sterile PBS to obtain $10^{9}$ bacteria per $100 \mu \mathrm{l}$ and administered by oral gavage.

Glycerol stocks were prepared using the same method as described in previous section. Streptomycin was used as a selection antibiotic. The viability of the stocks was tested by randomly choosing 3 samples and plating the bacteria on MacConkey agar (Sigma-Aldrich) containing $100 \mu \mathrm{g} / \mathrm{ml}$ of streptomycin (Sigma-Aldrich).

In vivo Ab administration. The depletion of NK cells and CD8 T cells was achieved by intraperitoneal (i.p.) administration of a dose of $250 \mu \mathrm{g}$ anti-NK1.1 and $400 \mu \mathrm{g}$ anti-CD8 in PBS at $48 \mathrm{~h}$ prior infection with $10^{7} \mathrm{Lm}-2 \mathrm{~W} 1 \mathrm{~S}$. Abs were provided by AstraZeneca. 
Fig. 8 DC provision of OX40L is redundant for efficient effector CD4 T cell responses to Salmonella typhimurium-2W1S. To investigate the role of

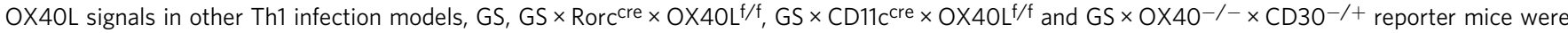
infected with intestinal pathogen Salmonella-2W1S via oral gavage $24 \mathrm{~h}$ post administration of streptomycin and the responses in the colon and mLN were assessed 7 days later. a Flow cytometric plots showing 2W1S-specific CD44hi CD4 T cell response and the eYFP expression in the colon of GS, GS $\times$ Rorc ${ }^{\mathrm{Cre}} \times \mathrm{OX} 4 \mathrm{OL}^{\mathrm{f} / \mathrm{f}}, \mathrm{GS} \times \mathrm{CD}_{11} \mathrm{c}^{\mathrm{cre}} \times \mathrm{OX} 4 \mathrm{OL}^{\mathrm{f} / \mathrm{f}}$ and $\mathrm{GS} \times \mathrm{OX} 40^{-/-} \times \mathrm{CD}^{-1 /+}$ mice at D7 post infection. $\mathbf{b}$ Enumeration of CD4 T cells in the colon. c Enumeration of 2W1S-specific CD4 T cells in colon. d Enumeration of eYFP+ 2W1S-specific CD4 T cells. e Percentage of 2W1S-specific CD4 T cells expressing eYFP. f Flow cytometric plots showing 2W1S-specific CD44hi CD4 T cell response and the eYFP expression in the mesenteric LN of GS, GS $\times$ Rorc ${ }^{\text {cre }} \times \mathrm{OX} 4 \mathrm{OL} / \mathrm{f}, \mathrm{GS} \times \mathrm{CD}_{11} \mathrm{c}^{\mathrm{cre}} \times \mathrm{OX} 4 \mathrm{OL} \mathrm{L}^{\mathrm{f} / \mathrm{f}}$ and $\mathrm{GS} \times \mathrm{OX} 40^{-/-} \times \mathrm{CD}^{-1+}$ mice at D7 post infection. $\mathrm{g}$ Enumeration of $2 \mathrm{~W} 1 \mathrm{~S}-\mathrm{specific} \mathrm{CD} 4 \mathrm{~T}$ cells in the mesenteric LN. h Enumeration of eYFP+ 2W1S-specific CD4 T cells. i Percentage of 2W1S-specific CD4 T cells expressing eYFP. Data were

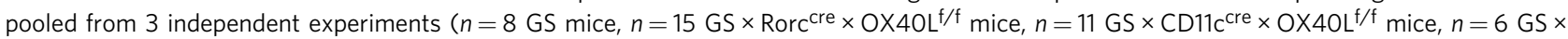
$\mathrm{OX} 40^{-/-} \times \mathrm{CD}^{-1+}$ mice). Values on flow cytometric plots represent percentages; bars on scatter plots represents the median. Statistical significance was tested by using Kruskal-Wallis one-way ANOVA with post hoc Dunn's test: ${ }^{\star} p \leq 0.05,{ }^{\star \star} p \leq 0.01$.

\section{Cell culture. Cell suspensions were prepared in sterile conditions.}

Experiments to assess OX40L expression in conditional OX40L-deficient mice: Assessment of OX40L expression on Ag-presenting ells, like dendritic cells and B cells, required overnight culture with CD40 stimulation. For this purpose, purified anti-CD40 Ab was added at $1 \mu \mathrm{g} / \mathrm{ml}$. To assess the expression of OX40L on T cells, $2 \times 10^{6}$ splenocytes were cultured at $37^{\circ} \mathrm{C}, 5 \% \mathrm{CO}_{2}$ for $72 \mathrm{~h}$ in the presence of $10 \mu \mathrm{g} / \mathrm{ml}$ Abatacept and $0.5 \mu \mathrm{g} / \mathrm{ml}$ functional-grade anti-CD3 $\varepsilon$.

Experiments to assess expression and regulation of OX40L on splenic DCs: In all, $2 \times 10^{6}$ splenocytes from uninfected or $L m-2 \mathrm{~W} 1 \mathrm{~S}$ infected mice were cultured overnight $(18-24 \mathrm{~h})$ at $37^{\circ} \mathrm{C}, 5 \% \mathrm{CO}_{2}$ in 24 -well plate in $1 \mathrm{ml}$ culture media (RPMI/10\% foetal bovine serum/L-Glu/penicillin and streptomycin), either alone or with $1 \mu \mathrm{g}$ anti-CD40 Abs or $100 \mathrm{ng}$ recombinant IFN $\gamma$ (Peprotech).

Experiments to detect IFN $\gamma$ production by NK cells: Splenocytes from mice infected with $L m-2 \mathrm{~W} 1 \mathrm{~S} 24 \mathrm{~h}$ previously were cultured for $3 \mathrm{~h}$ in culture media in the presence of brefeldin A $(10 \mu \mathrm{g} / \mathrm{ml})$ and then analysed by flow cytometry.

Flow cytometry. Spleens were teased using fine forceps and digested for $25 \mathrm{~min}$ in RPMI containing with $250 \mu \mathrm{g} / \mathrm{ml}$ Collagenase-Dispase (Roche) and $25 \mu \mathrm{g} / \mathrm{ml}$ DNase I (Sigma). Digested tissue was then crushed through a nylon mesh, treated with Gey's solution red blood lysis buffer and resuspended in appropriate volume of staining buffer. Splenocytes were re-filtered prior to use. Staining for 2 W 1 S:I-A $A^{b}$ MHCII Tetramer and CXCR5 was performed for $1 \mathrm{~h}$ at room temperature (RT). Surface staining was performed at $+4{ }^{\circ} \mathrm{C}$ for $30 \mathrm{~min}$. Intracellular staining was done using the FoxP3 Fixation and Permeabilisation Kit (eBioscience) or Cytofix/ Cytoperm Plus (BD Biosciences), both according to the manufacturer's instructions. Abs raised against the following mouse agents were used: B220 (1:300 or 1:200; clone RA3-6B2, eBioscience), CCR6 (1:100; clone 29-2L17, eBioscience), CD3 (1:100 or 1:200; clone 145-2C11 or 17A2; eBioscience, BD Biosciences, or BioLegend), CD4 (1:200 or 1:300; clone RM4 ${ }^{-} 5$, BioLegend, eBioscience), CD8 (1:100 or 1:200; clone 53-6.7, eBioscience), CD11b (1:100 or 1:200; clone M1/70, eBioscience), CD11c (1:200 or 1:300; clone N418, eBioscience), CD25 (1:200; clone PC61, BioLegend), CD44 (1:200; clone IM7, eBioscience), CD49b (1:100; clone DX5, eBioscience), CD86 (1:100 or 1:600; clone GL-1, BioLegend), CXCR5 (1:50; clone 2G8, BD Biosciences), EOMES (1:50; clone Dan11mag, eBioscience), IFN $\gamma$ (1:200 or 1:300; clone XMG1.2, eBioscience or BioLegend), IFN $\gamma \mathrm{R}$ (1:100; clone 2E2, eBioscience), IL-7Ra (1:100; clone A7R34, BioLegend), Ly6c (1:800; clone HK1.4, BioLegend), MHCII (1:500; clone M5/114.15.2, eBioscience), NK1.1 (1:100; clone PK136, BD Biosciences or eBioscience), NKp46 (1:100; clone 29A1.4, BioLegend), OX40 (1:25; clone OX86, eBioscience), OX40L (1:50; clone RM134L, BioLegend), T-bet (1:50; clone 4B10, eBioscience), and TCR $\beta$ (1:100; clone H57-597, Biolegend). Addition of Spherotech Accucount blank particles was done to calculate cell frequencies. Flow cytometry was performed on a Fortessa analyser using the FACSDiva 8.0.2 software (BD), with data subsequently analysed with the FlowJo software version 10 (Tree Star).

Immunofluorescence detection of IFN $\boldsymbol{\gamma}$ expression in situ. Procedure has been performed as previously described ${ }^{69}$. Briefly, WT mice were infected with $10^{4}$ colony-forming units $L m$ OVA. Mice were given $250 \mu \mathrm{g}$ brefeldin A by i.p. injection, $6 \mathrm{~h}$ before being sacrificed. After $24 \mathrm{~h}$, mice were euthanised, and the spleens were removed, fixed in $4 \%$ PFA and cryopreserved in OCT. Serial sections $(30 \mu \mathrm{m}$ in thickness) of frozen spleens were stained overnight at $+4^{\circ} \mathrm{C}$ in a humidified chamber with the following Abs: anti-B220 PB (1:300; 103230, Biolegend), antiCD169 Alexa647 (1:300; 142407, Biolegend), anti-CD8 BV510 (1:100; 100751, Biolegend), anti-IFN $\gamma$ BV421 (1:200; 505829, Biolegend), anti-I-A/I-E biotin (1:200; 107603, Biolegend), or anti-NKp46 (1:200; AF2225, R\&D). For secondary detection, sections were then washed and incubated with Streptavidin-Cy3 (1:200; 016-160-084, Jackson Immunoresearch) and anti-goat IgG A647 (1:500; ab150131; Abcam) for $3 \mathrm{~h}$ at RT. All sections were analysed by confocal microscopy. Quantification of the interaction between DCs and IFN $\gamma$-producing cells was performed manually. DCs were randomly selected in the IFN $\gamma$-rich area. For each DC, the number of IFN $\gamma$-producing CD8 T cells and the number of IFN $\gamma$-producing NK cells was recorded and averaged.
Human subjects. All analyses of human data were carried out in compliance with the relevant ethical regulations. Healthy blood donors gave informed consent at DRK Dresden, Germany, and buffy coats were obtained as approved by Charité ethics committee (EA4/059/17).

In vitro culture of human CDC2 and NK cells. Peripheral blood mononuclear cells were isolated from buffy coats by density gradient centrifugation (Ficoll Paque Plus, GE Healthcare). CD56 ${ }^{+}$and $\mathrm{CD} 19^{+}$cells were depleted (CD56, CD19 microbeads and LD-columns, Miltenyi Biotec), the remaining cells were stained with biotinylated anti-CD1c Ab $\left(1: 50 ; 130-110-535\right.$, Miltenyi Biotec) and CD1c ${ }^{+}$ cells were enriched (anti-Biotin microbeads and LS-columns, Miltenyi Biotec). cDC2 were sorted from the CD1c-enriched fraction as viable $\mathrm{CD} 14^{-} \mathrm{CD} 1 \mathrm{c}^{+}$cells (Supplementary Fig. 8a). Pure NK cells were sorted on a FACS Aria II (BD) from the $\mathrm{CD} 56^{+} / \mathrm{CD} 19^{+}$fraction as viable $\mathrm{CD} 14^{-} \mathrm{CD}^{-} 9^{-} \mathrm{CD} 3^{-} \mathrm{CD} 56^{+} \mathrm{CD}^{-} 7^{-}$ lymphocytes (shown in Supplementary Fig. 8b), using anti-CD14 (1:50; 301820, Biolegend), anti-CD19 (1:50; 302216, Biolegend), anti-CD3 (1:50, generated in house), anti-CD56 (1:200, 318306, Biolegend) and anti-CD57 (1:50, 393304, Biolegend) Abs. Autologous NK cells and $\mathrm{cDC} 2$ were mixed at atio of 2:1 and cultured in RPMI-1640 (Gibco) supplemented with $10 \%$ foetal calf serum at the indicated conditions for $40 \mathrm{~h}$. Where indicated, recombinant IFN $\gamma$ (Miltenyi Biotec) was added at a concentration of $100 \mathrm{ng} / \mathrm{ml}$ and IL-12 and IL-15 (both Miltenyi Biotec) at $50 \mathrm{ng} / \mathrm{ml}$ each. After $40 \mathrm{~h}$, cells were stained and analysed on a FACS Aria II (BD) using these additional Abs: anti-HLA-DR (1:200; generated in house), anti-CD86 (1:50; 130-114-095, Miltenyi), anti-OX40L (1:100; 326308, Biolegend), anti-CD40 (1:50; 334336, Biolegend), and anti-CD3 (1:50; 47-0036-42, eBioscience)

RNA extraction of $\mathbf{L m}-\mathbf{2 W} 1 \mathrm{~S}-\mathrm{stimulated} \mathrm{DC}$ and reverse transcriptase (RT)

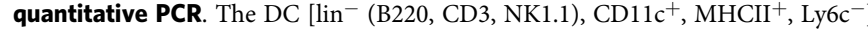
were sorted at $4 \mathrm{~h}$ post infection with Lm-2W1S. Total RNA was extracted from Buffer RLT with $1 \% \beta$-mercaptoethanol (Sigma-Aldrich)-conserved DC using the RNeasy ${ }^{\circledast}$ Mini Kit (Qiagen), according to the manufacturer’s instructions. RNA samples were stored at $-80^{\circ} \mathrm{C}$ until conversion into cDNA.

RNA was reverse-transcribed with SuperScript ${ }^{\mathrm{TM}}$ III RT (Invitrogen ${ }^{\mathrm{TM}}$ ThermoFisher Scientific) using oligo-dT strategy and according to the manufacturer's instructions. To synthesise cDNA, $1 \mu$ l of oligo (dT) primer, $1 \mu \mathrm{l}$ of $10 \mathrm{mM}$ stock of dNTPs (Invitrogen) and $11 \mu \mathrm{l}$ of total RNA in Nuclease-free water were incubated at $65^{\circ} \mathrm{C}$ for $5 \mathrm{~min}$ and then put on ice for $3 \mathrm{~min}$. The following reagents were added: $4 \mu \mathrm{l}$ of $5 \times$ First strand buffer (Invitrogen), $1 \mu$ RNase OUT (Invitrogen), $1 \mu \mathrm{l}$ of $0.1 \mathrm{M}$ dithiothreitol (Invitrogen) and $1 \mu \mathrm{l}$ of $200 \mathrm{units} / \mu \mathrm{l}$ Superscript III RT (Invitrogen) followed by incubation at $50^{\circ} \mathrm{C}$ for $60 \mathrm{~min}$. Reaction was inactivated for $15 \mathrm{~min}$ at $72^{\circ} \mathrm{C}$. To remove RNA complementary to the cDNA, $1 \mu \mathrm{l}$ ( 2 units) of RNase $\mathrm{H}$ were added, and the reaction mixture was incubated at $37^{\circ} \mathrm{C}$ for $20 \mathrm{~min}$. cDNA samples were stored as multiple aliquots at $-20^{\circ} \mathrm{C}$ for subsequent use.

Quantitative real-time PCR. cDNA was amplified with the SensiFAST ${ }^{\mathrm{TM}} \mathrm{SYBR}^{\circledR}$ Hi-Rox Kit (Bioline Meridian Bioscience), according to the manufacturer's instructions. Amplification reactions and detections were performed on ABI PRISM 7900HT Sequence Detection System (Applied Biosystems ${ }^{\mathrm{TM}}$ ThermoFisher Scientific): $50^{\circ} \mathrm{C} 2 \mathrm{~min}, 95^{\circ} \mathrm{C} 10 \mathrm{~min},\left[95^{\circ} \mathrm{C} 15 \mathrm{~s} ; 60^{\circ} \mathrm{C} 1 \mathrm{~min}\right] \times 40$.

Primers used were Il12a p35 (Mm_Il12a_1_SG Qiagen QT01048334) and Il12b p40 (Mm_Il12b_1_SG Qiagen QT00153643). Each sample was run in triplicates, and the levels of the mRNA detected were normalised to $\beta$-actin. Data were analysed by calculating the relative expression of the target to $\beta$-actin in each sample $=2^{\Delta \mathrm{Ct}}$ (with $\Delta \mathrm{Ct}=\mathrm{Ct}_{\beta \text {-actin }}-\mathrm{Ct}_{\text {target }}$ ).

Statistical analysis. Data were analysed using GraphPad Prism (version 8). Nonparametric Mann-Whitney, two tailed or non-parametric Kruskal-Wallis one-way analysis of variance (ANOVA) with post hoc Dunn's tests or, following the successful normality tests, ordinary one-way ANOVA with post hoc Tukey's tests were 
used to determine significance, which was set at $p \leq 0.05$. Median values were calculated and used in all analyses unless stated.

Reporting summary. Further information on research design is available in the Nature Research Reporting Summary linked to this article.

\section{Data availability}

All data are available on request. Source data are provided with this paper.

Received: 7 January 2019; Accepted: 23 June 2020;

Published online: 09 July 2020

\section{References}

1. Ward-Kavanagh, L. K., Lin, W. W., Sedy, J. R. \& Ware, C. F. The TNF receptor superfamily in co-stimulating and co-inhibitory responses. Immunity 44, 1005-1019 (2016).

2. Watts, T. H. TNF/TNFR family members in costimulation of $\mathrm{T}$ cell responses. Annu. Rev. Immunol. 23, 23-68 (2005).

3. Croft, M. Co-stimulatory members of the TNFR family: keys to effective T-cell immunity? Nat. Rev. Immunol. 3, 609-620 (2003).

4. Croft, M. The role of TNF superfamily members in T-cell function and diseases. Nat. Rev. Immunol. 9, 271-285 (2009).

5. Croft, M. Control of immunity by the TNFR-related molecule OX40 (CD134). Annu. Rev. Immunol. 28, 57-78 (2010).

6. Dawicki, W., Bertram, E. M., Sharpe, A. H. \& Watts, T. H. 4-1BB and OX40 act independently to facilitate robust CD8 and CD4 recall responses. J. Immunol. 173, 5944-5951 (2004).

7. Gramaglia, I. et al. The OX40 costimulatory receptor determines the development of CD4 memory by regulating primary clonal expansion. J. Immunol. 165, 3043-3050 (2000).

8. Soroosh, P., Ine, S., Sugamura, K. \& Ishii, N. Differential requirements for OX40 signals on generation of effector and central memory CD4+ T cells. J. Immunol. 179, 5014-5023 (2007).

9. Rogers, P. R., Song, J., Gramaglia, I., Killeen, N. \& Croft, M. OX40 promotes $\mathrm{Bcl}-\mathrm{xL}$ and $\mathrm{Bcl}-2$ expression and is essential for long- term survival of CD4 T cells. Immunity 15, 445-455 (2001).

10. Byun, M. et al. Inherited human OX40 deficiency underlying classic Kaposi sarcoma of childhood. J. Exp. Med. 210, 1743-1759 (2013).

11. Gaspal, F. et al. Critical synergy of CD30 and OX40 signals in CD4 T cell homeostasis and Th1 immunity to Salmonella. J. Immunol. 180, 2824-2829 (2008).

12. Gaspal, F. et al. Abrogation of CD30 and OX40 signals prevents autoimmune disease in FoxP3-deficient mice. J. Exp. Med. 208, 1579-1584 (2011).

13. Gaspal, F. M. et al. Mice deficient in OX40 and CD30 signals lack memory antibody responses because of deficient CD4 T cell memory. J. Immunol. 174 3891-3896 (2005).

14. Linton, P. J. et al. Costimulation via OX40L expressed by B cells is sufficient to determine the extent of primary CD4 cell expansion and Th2 cytokine secretion in vivo. J. Exp. Med. 197, 875-883 (2003).

15. Arestides, R. S. et al. Costimulatory molecule OX40L is critical for both Th1 and Th2 responses in allergic inflammation. Eur. J. Immunol. 32, 2874-2880 (2002).

16. Jenkins, S. J., Perona-Wright, G., Worsley, A. G., Ishii, N. \& MacDonald, A. S. Dendritic cell expression of OX40 ligand acts as a costimulatory, not polarizing, signal for optimal Th2 priming and memory induction in vivo. $J$. Immunol. 179, 3515-3523 (2007).

17. Kopf, M. et al. OX40- deficient mice are defective in Th cell proliferation but are competent in generating B cell and CTL responses after virus infection. Immunity 11, 699-708 (1999).

18. Ito, T. et al. TSLP-activated dendritic cells induce an inflammatory $\mathrm{T}$ helper type 2 cell response through OX40 ligand. J. Exp. Med. 202, 1213-1223 (2005).

19. Xiao, X. et al. The costimulatory receptor OX40 inhibits interleukin-17 expression through activation of repressive chromatin remodeling pathways. Immunity 44, 1271-1283 (2016)

20. Stüber, E., Neurath, M., Calderhead, D., Fell, H. P. \& Strober, W. Crosslinking of OX40 ligand, a member of the TNF/NGF cytokine family, induces proliferation and differentiation in murine splenic B cells. Immunity 2, 507-521 (1995).

21. Ohshima, Y. et al. Expression and function of OX40 ligand on human dendritic cells. J. Immunol. 159, 3838-3848 (1997).

22. Takasawa, N. et al. Expression of gp34 (OX40 ligand) and OX40 on human T cell clones. Jpn. J. Cancer Res. 92, 377-382 (2001).
23. Kim, M. Y. et al. CD4(+)CD3(-) accessory cells costimulate primed CD4 $\mathrm{T}$ cells through OX40 and CD30 at sites where T cells collaborate with B cells. Immunity 18, 643-654 (2003).

24. Imura, A. et al. The human OX40/gp34 system directly mediates adhesion of activated T cells to vascular endothelial cells. J. Exp. Med. 183, 2185-2191 (1996).

25. Burgess, J. K. et al. Detection and characterization of OX40 ligand expression in human airway smooth muscle cells: a possible role in asthma? J. Allergy Clin. Immunol. 113, 683-689 (2004).

26. Mempel, T. R., Henrickson, S. E. \& Von Andrian, U. H. T-cell priming by dendritic cells in lymph nodes occurs in three distinct phases. Nature 427, 154-159 (2004).

27. Stoll, S., Delon, J., Brotz, T. M. \& Germain, R. N. Dynamic imaging of T cell dendritic cell interactions in lymph nodes. Science 296, 1873-1876 (2002).

28. Bousso, P. \& Robey, E. Dynamics of CD8+ T cell priming by dendritic cells in intact lymph nodes. Nat. Immunol. 4, 579-585 (2003).

29. Kerfoot, S. M. et al. Germinal center B cell and T follicular helper cell development initiates in the interfollicular zone. Immunity 34, 947-960 (2011).

30. Withers, D. R. et al. Cutting edge: lymphoid tissue inducer cells maintain memory CD4 T cells within secondary lymphoid tissue. J. Immunol. 189, 2094-2098 (2012)

31. Mackley, E. C. et al. CCR7-dependent trafficking of RORgamma(+) ILCs creates a unique microenvironment within mucosal draining lymph nodes. Nat. Commun. 6, 5862 (2015).

32. Kim, M.-Y. et al. OX40-ligand and CD30-ligand are expressed on adult but not neonatal CD4+CD3- inducer cells: evidence that IL7 signals regulate CD30-ligand but not OX40-ligand expression. J. Immunol. 174, 6686-6691 (2005).

33. von Burg, N. et al. Activated group 3 innate lymphoid cells promote T-cellmediated immune responses. Proc. Natl Acad. Sci. USA 111, 12835-12840 (2014).

34. Marriott, C. L. et al. OX40 controls effector CD4+ T-cell expansion, not follicular $\mathrm{T}$ helper cell generation in acute Listeria infection. Eur. J. Immunol. 44, 2437-2447 (2014)

35. Boettler, T. et al. Exogenous OX40 stimulation during lymphocytic choriomeningitis virus infection impairs follicular Th cell differentiation and diverts CD4 T cells into the effector lineage by upregulating Blimp-1. J. Immunol. https://doi.org/10.4049/jimmunol.1300013 (2013).

36. Price, A. E., Reinhardt, R. L., Liang, H. E. \& Locksley, R. M. Marking and quantifying IL-17A-producing cells in vivo. PLoS ONE 7, e39750 (2012)

37. Pepper, M. et al. Different routes of bacterial infection induce long-lived TH memory cells and short-lived TH17 cells. Nat. Immunol. 11, 83-89 (2010).

38. Pepper, M., Pagan, A. J., Igyarto, B. Z., Taylor, J. J. \& Jenkins, M. K. Opposing signals from the Bcl6 transcription factor and the interleukin-2 receptor generate $\mathrm{T}$ helper 1 central and effector memory cells. Immunity 35, 583-595 (2011).

39. Cortini, A. et al. B cell OX40L supports T follicular helper cell development and contributes to SLE pathogenesis. Ann. Rheum. Dis. 76, 2095-2103 (2017).

40. Scharton, T. M. \& Scott, P. Natural killer cells are a source of interferon gamma that drives differentiation of $\mathrm{CD} 4+\mathrm{T}$ cell subsets and induces early resistance to Leishmania major in mice. J. Exp. Med. 178, 567-577 (1993).

41. Takeda, K. et al. Defective NK cell activity and Th1 response in IL-18-deficient mice. Immunity 8, 383-390 (1998).

42. Manetti, R. et al. Natural killer cell stimulatory factor (interleukin 12 [IL-12]) induces $\mathrm{T}$ helper type 1 (Th1)-specific immune responses and inhibits the development of IL-4-producing Th cells. J. Exp. Med. 177, 1199-1204 (1993).

43. Coccia, M. et al. Cellular and molecular synergy in AS01-adjuvanted vaccines results in an early IFNgamma response promoting vaccine immunogenicity. NPJ Vaccines 2, 25 (2017).

44. Gerosa, F. et al. Reciprocal activating interaction between natural killer cells and dendritic cells. J. Exp. Med. 195, 327-333 (2002).

45. Hsieh, C. S. et al. Development of TH1 CD4+ T cells through IL-12 produced by Listeria-induced macrophages. Science 260, 547-549 (1993).

46. Humann, J. \& Lenz, L. L. Activation of naive NK cells in response to Listeria monocytogenes requires IL-18 and contact with infected dendritic cells. J. Immunol. 184, 5172-5178 (2010)

47. Tripp, C. S., Gately, M. K., Hakimi, J., Ling, P. \& Unanue, E. R. Neutralization of IL-12 decreases resistance to Listeria in SCID and C.B-17 mice. Reversal by IFN-gamma. J. Immunol. 152, 1883-1887 (1994).

48. Carnaud, C. et al. Cutting edge: cross-talk between cells of the innate immune system: NKT cells rapidly activate NK cells. J. Immunol. 163, 4647-4650 (1999).

49. Mooney, J. P. et al. Transient loss of protection afforded by a live attenuated non-typhoidal Salmonella vaccine in mice co-infected with malaria. PLoS Negl. Trop. Dis. 9, e0004027 (2015). 
50. Castellanos, J. G. et al. Microbiota-induced TNF-like ligand 1A drives group 3 innate lymphoid cell-mediated barrier protection and intestinal $\mathrm{T}$ cell activation during colitis. Immunity 49, 1077-1089 e1075 (2018).

51. Withers, D. R. et al. The survival of memory CD4 $+\mathrm{T}$ cells within the gut lamina propria requires OX40 and CD30 signals. J. Immunol. 183, 5079-5084 (2009).

52. Kambayashi, T. \& Laufer, T. M. Atypical MHC class II-expressing antigenpresenting cells: can anything replace a dendritic cell? Nat. Rev. Immunol. 14, 719-730 (2014).

53. Neighbors, M. et al. A critical role for interleukin 18 in primary and memory effector responses to Listeria monocytogenes that extends beyond its effects on Interferon gamma production. J. Exp. Med. 194, 343-354 (2001).

54. Shibuya, K. et al. IL-1 alpha and TNF-alpha are required for IL-12-induced development of Th1 cells producing high levels of IFN-gamma in BALB/c but not C57BL/6 mice. J. Immunol. 160, 1708-1716 (1998).

55. Deng, T. et al. ILC3-derived OX40L is essential for homeostasis of intestinal Tregs in immunodeficient mice. Cell. Mol. Immunol. https://doi.org/10.1038/ s41423-019-0200-x (2019).

56. Hepworth, M. R. et al. Immune tolerance. Group 3 innate lymphoid cells mediate intestinal selection of commensal bacteria-specific CD4 $(+) \mathrm{T}$ cells. Science 348, 1031-1035 (2015).

57. Hepworth, M. R. et al. Innate lymphoid cells regulate CD4+ T-cell responses to intestinal commensal bacteria. Nature 498, 113-117 (2013).

58. Melo-Gonzalez, F. \& Hepworth, M. R. Functional and phenotypic heterogeneity of group 3 innate lymphoid cells. Immunology 150, 265-275 (2017).

59. Withers, D. R. Innate lymphoid cell regulation of adaptive immunity. Immunology 149, 123-130 (2016).

60. Tubo, N. J. et al. Single naive CD4 $+\mathrm{T}$ cells from a diverse repertoire produce different effector cell types during infection. Cell 153, 785-796 (2013).

61. Johnston, R. J. et al. Bcl6 and Blimp-1 are reciprocal and antagonistic regulators of $\mathrm{T}$ follicular helper cell differentiation. Science 325, 1006-1010 (2009).

62. McCaughtry, T. M. et al. Conditional deletion of cytokine receptor chains reveals that IL-7 and IL-15 specify CD8 cytotoxic lineage fate in the thymus. J. Exp. Med. 209, 2263-2276 (2012).

63. Hashimoto, K., Joshi, S. K. \& Koni, P. A. A conditional null allele of the major histocompatibility IA-beta chain gene. Genesis 32, 152-153 (2002).

64. Mattner, F. et al. Genetically resistant mice lacking interleukin-12 are susceptible to infection with Leishmania major and mount a polarized Th2 cell response. Eur. J. Immunol. 26, 1553-1559 (1996).

65. Lee, S. H. et al. Identifying the initiating events of anti-Listeria responses using mice with conditional loss of IFN-gamma receptor subunit 1 (IFNGR1). J. Immunol. 191, 4223-4234 (2013).

66. Muzumdar, M. D., Tasic, B., Miyamichi, K., Li, L. \& Luo, L. A global doublefluorescent Cre reporter mouse. Genesis 45, 593-605 (2007).

67. Lallemand, Y., Luria, V., Haffner-Krausz, R. \& Lonai, P. Maternally expressed PGK-Cre transgene as a tool for early and uniform activation of the Cre sitespecific recombinase. Transgenic Res 7, 105-112 (1998).

68. Eberl, G. \& Littman, D. R. Thymic origin of intestinal alphabeta T cells revealed by fate mapping of RORgammat + cells. Science 305, 248-251 (2004).

69. Mazet, J. M., Chiodetti, A. L., Mahale, J. N. \& Gerard, A. Imaging of in situ interferon gamma production in the mouse spleen following Listeria monocytogenes infection. J. Vis. Exp. https://doi.org/10.3791/59819 (2019)

\section{Acknowledgements}

The following tetramer was obtained through the NIH Tetramer Facility: 2W1S:I-A ${ }^{\mathrm{b}}$. We thank Dr. M. Jenkins (Lm-2W1S) and Dr. S. McSorley (Salmonella-2W1S) for provision of bacterial strains. We thank the following for their kind provision of mice: Dr. Adam Cunningham (Ifn $\gamma^{-l-}$ mice), Dr. Daniela Finke (H2-Ab1 ${ }^{\mathrm{f} / \mathrm{f}}$ mice), Dr. Dan Littman (Rorc ${ }^{\text {cre }}$ mice), Dr. Nick Jones (CD1d ${ }^{-1-}$ mice), Dr. Richard Locksley (Great $\times$ Smart17A mice), Dr. Michael Reth (Mb1 $\left.{ }^{\text {cre }}\right)$, and Dr. Alfred Singer (E8111 ${ }^{\text {cre }}$ mice). We thank Dr. Gianluca Carlesso and AstraZeneca for their kind provision of anti-NK1.1 and anti-CD8 Abs for in vivo depletion experiments. This work was supported by a Senior Research Fellowship from the Wellcome Trust to DRW (Grant Number 110199/Z/15/Z).

\section{Author contributions}

D.W.G. designed and performed experiments and wrote the manuscript; F.G., E.E.H., R.F., E.E.D., C.W. and S.L.B. performed and assisted with experiments; T.R., C.R. and A.G. designed, performed and analysed experiments; A.S.M. provided IL-12p35 $5^{-l-}$ mice, critiqued data and helped design experiments; M.B. and T.V. generated and provided OX40L $\mathrm{L}^{\mathrm{f} / \mathrm{f}}$ mice and critiqued data; D.R.W. designed experiments, critiqued data and wrote the manuscript.

\section{Competing interests}

The authors declare no competing interests.

\section{Additional information}

Supplementary information is available for this paper at https://doi.org/10.1038/s41467020-17293-3.

Correspondence and requests for materials should be addressed to D.R.W.

Peer review information Nature Communications thanks Guido Ferlazzo and the other anonymous reviewer(s) for their contribution to the peer review of this work.

Reprints and permission information is available at http://www.nature.com/reprints

Publisher's note Springer Nature remains neutral with regard to jurisdictional claims in published maps and institutional affiliations.

(c) (i)

Open Access This article is licensed under a Creative Commons Attribution 4.0 International License, which permits use, sharing, adaptation, distribution and reproduction in any medium or format, as long as you give appropriate credit to the original author(s) and the source, provide a link to the Creative Commons license, and indicate if changes were made. The images or other third party material in this article are included in the article's Creative Commons license, unless indicated otherwise in a credit line to the material. If material is not included in the article's Creative Commons license and your intended use is not permitted by statutory regulation or exceeds the permitted use, you will need to obtain permission directly from the copyright holder. To view a copy of this license, visit http://creativecommons.org/ licenses/by/4.0/.

(C) The Author(s) 2020 